\title{
Post Market Monitoring of GM Herbicide-Tolerant Crops
}

\author{
by \\ Dr. Alan M. Dewar \\ Dewar Crop Protection Ltd
}

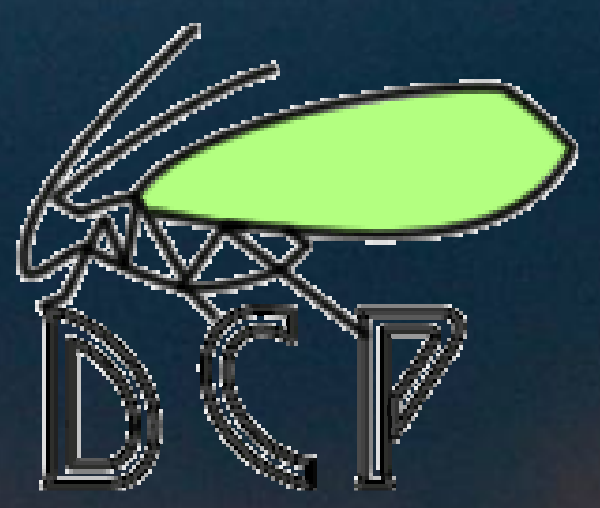




\section{Determination of Measurement End Points for crop monitoring}

- Endpoint must be valid indicator of impact

- Taxonomic resolution must be appropriate

- Protocols should have appropriate temporal and spatial properties

- Statistical power should be appropriate to detect changes

- The statistical and biological validity should not be compromised by logistic and/or financial pressures 


\section{What should post monitoring of GMHT crops be looking at?}

- Adverse effects on plants esp. weeds?

- Adverse effects on associated wildlife?

- Adverse effects on birds?

- Adverse effects on biodiversity?

- Escapes to non-agricultural environments?

- Gene flow to non GM crops or related species?

- Herbicide residues in local waterways?

- Development of resistance to associated herbicides? 


\section{Who should pay for it?}

- The manufacturer's who will just put the cost on the product and seed?

- The farmer?

- The government's of Europe i.e. the taxpayer?

- The green lobby? 


\section{Is weed control absolutely necessary?}

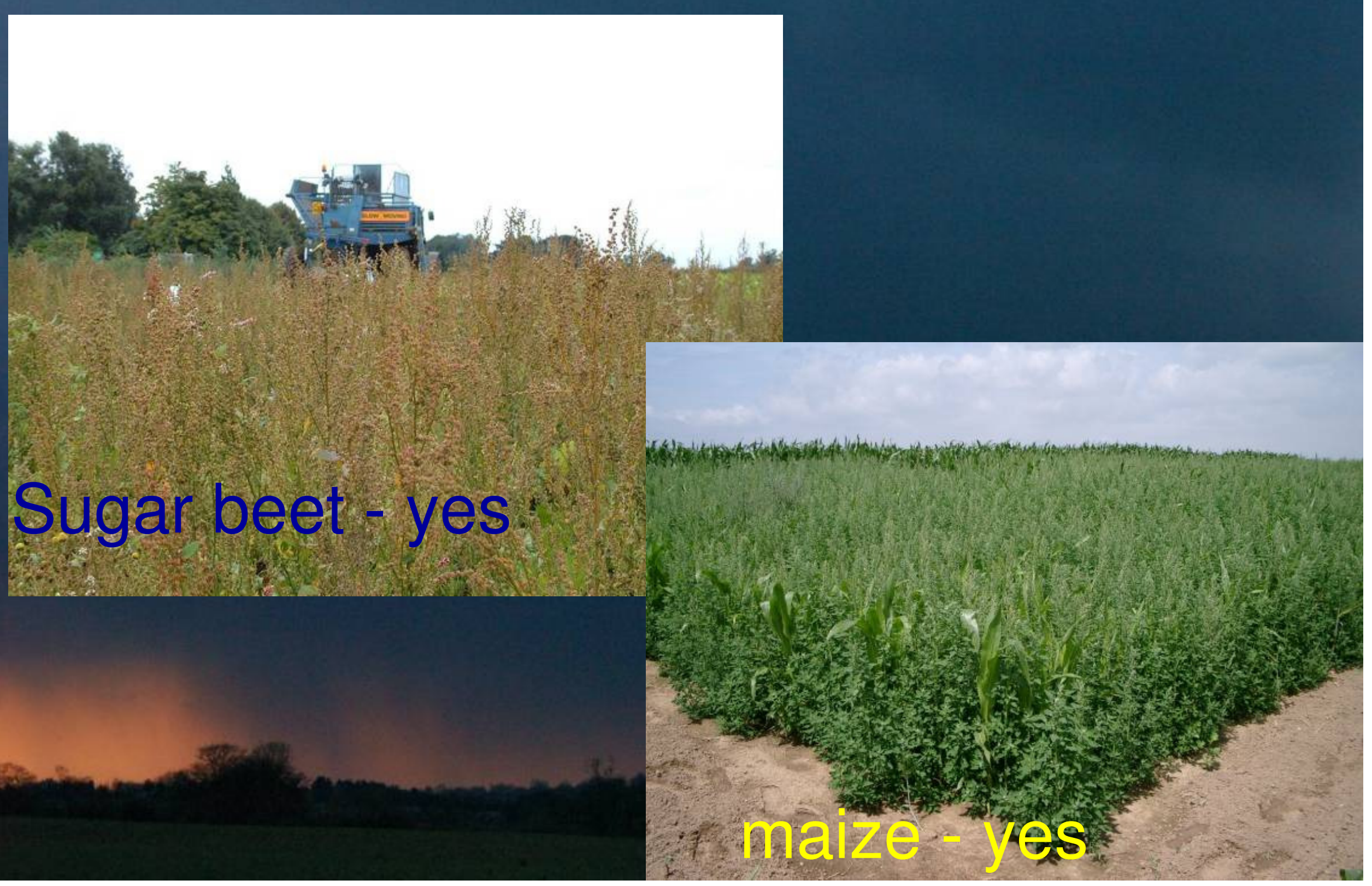




\section{However, does it need to be perfect? Like this? Or will this do?}

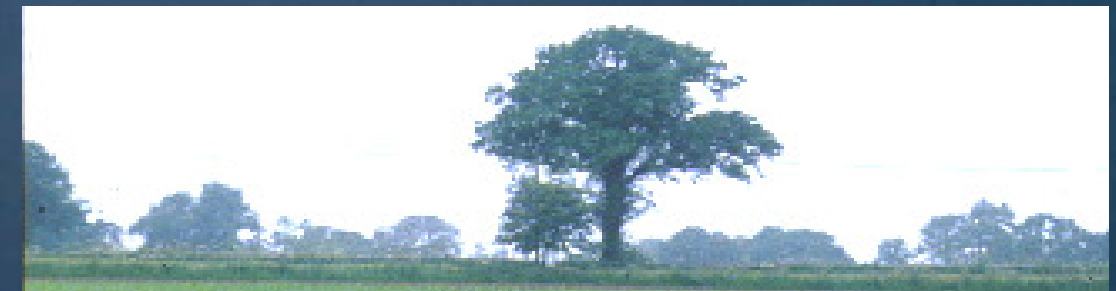

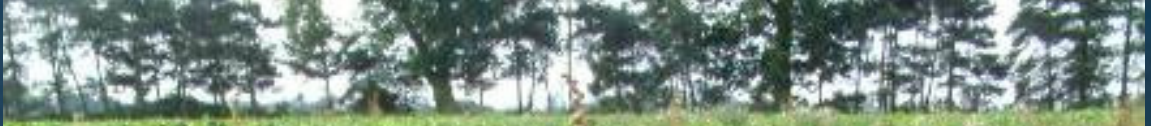

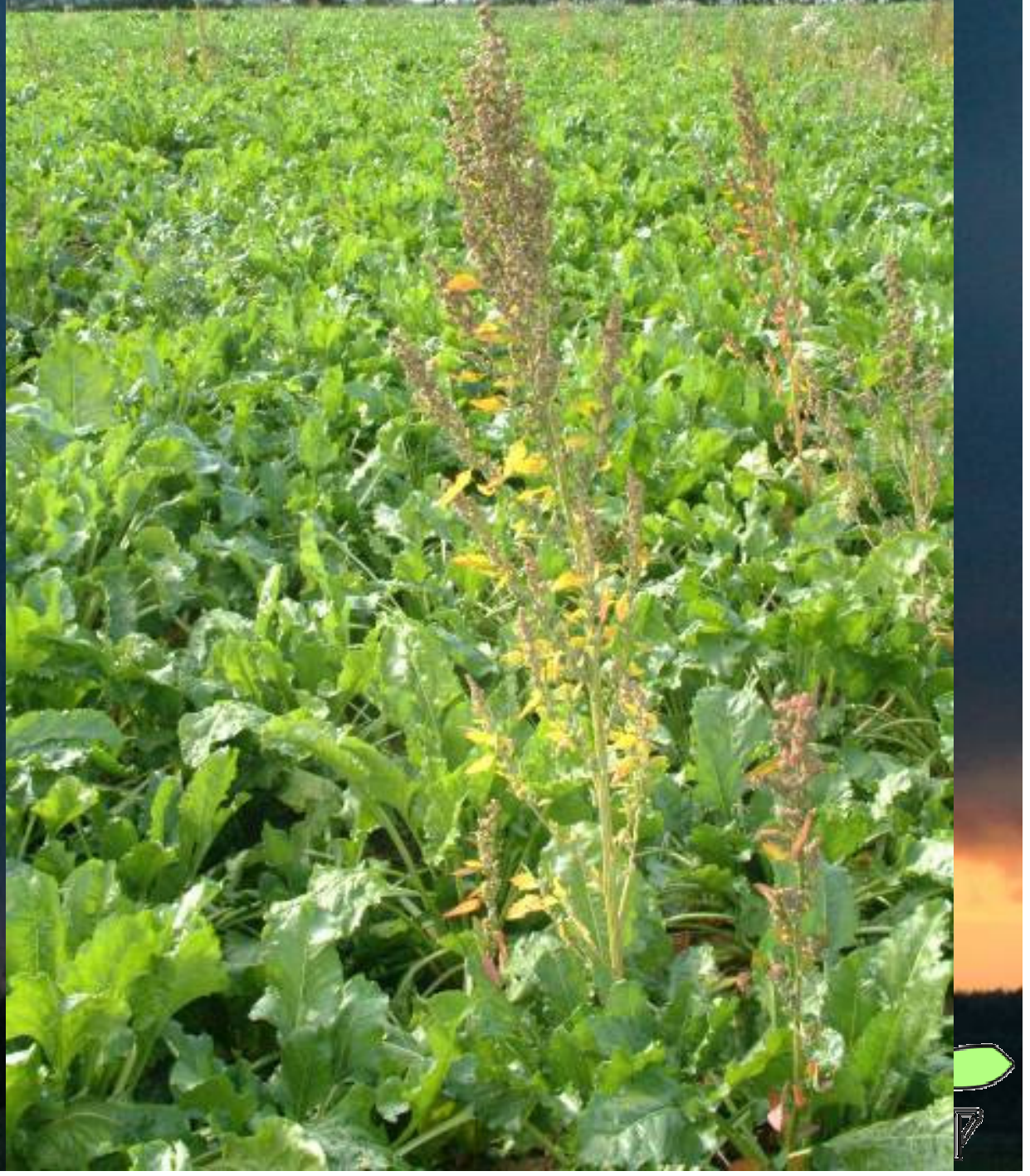




\section{Weed control affects the environment - however it is achieved}
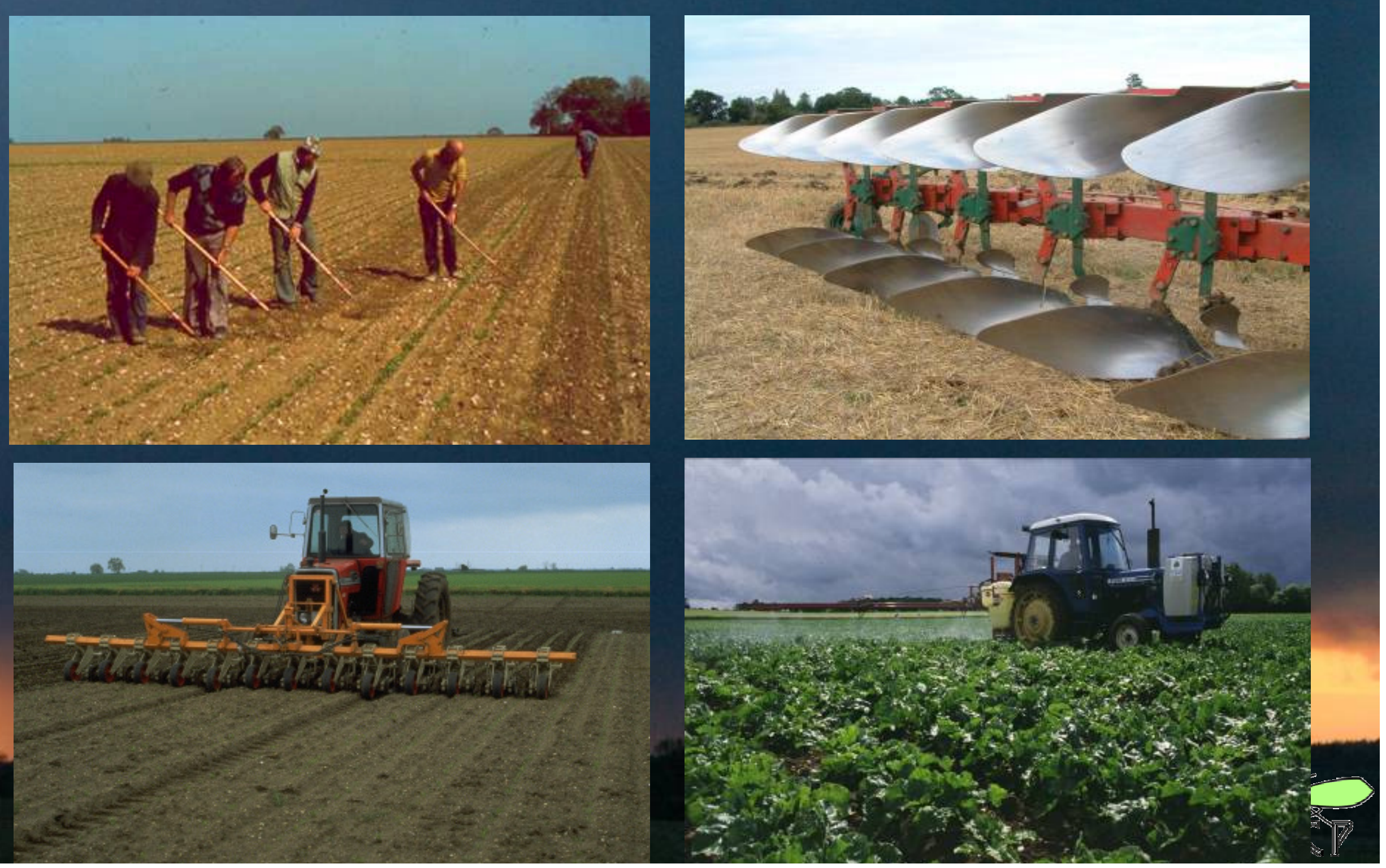


\section{So why is there so much focus on GMHT crops?}

All new agricultural practices (and probably existing practices too) should be assessed in the same way 


\section{GMHT - costs \& beneffits}

- Possible benefits

- reduced use of herbicides

- use of less persistent herbicides

- can apply sprays later

- less need for insurance sprays

- greater potential to use no-till cultivations

- Possible harm

- greater efficiency of weed control

- will be used to clean up weedier fields

- can have effects on biodiversity, especially invertebrates \& birds

- can further limit ecosystem services 
It was for these reasons that the UK government set up the Farm Scale

Evaluations in 1999

to determine the impact of GM crops on

the environment -

pre-marketing!

These approaches, or some of them, could however also be considered for post market monitoring 


\section{The Farm Scale Evaluations}

- The null hypothesis was that there is no difference between the management of GMHT varieties and that of comparable conventional varieties, in their effect on the abundance and diversity of arable plants and invertebrates.

- Focus on wildlife - not food safety or gene flow

"This research will not only address GM crops. This is an extremely important opportunity to gain a more detailed understanding of the effects of agricultural management on farmland wildlife generally" Michael Meacher, Minister for the Environment 1999 


\section{Treatments}

-Non GM variety + Conventional herbicide programme

-GMHT variety + broad spectrum herbicide to which it was tolerant

-For beet - glyphosate (Roundup Biactive) -For maize and spring and winter rape

- glufosinate ammonium (Liberty) 


\section{Design considerations}

- Halved-fields

- Conventional herbicides should be applied according to normal practice

- GMHT management should give cost-effective weed control

- Power (replication) - aimed for $80 \%$ chance to detect x 1.5fold effect - for all three crops this meant 60-70 replicates

- Sites - should be representative of where the crops are grown in UK

- Farms - should aim to include relatively large proportion of less-intensively managed farms (although not many volunteered) 


\section{Sampling within half-fields}

9 margin sample areas

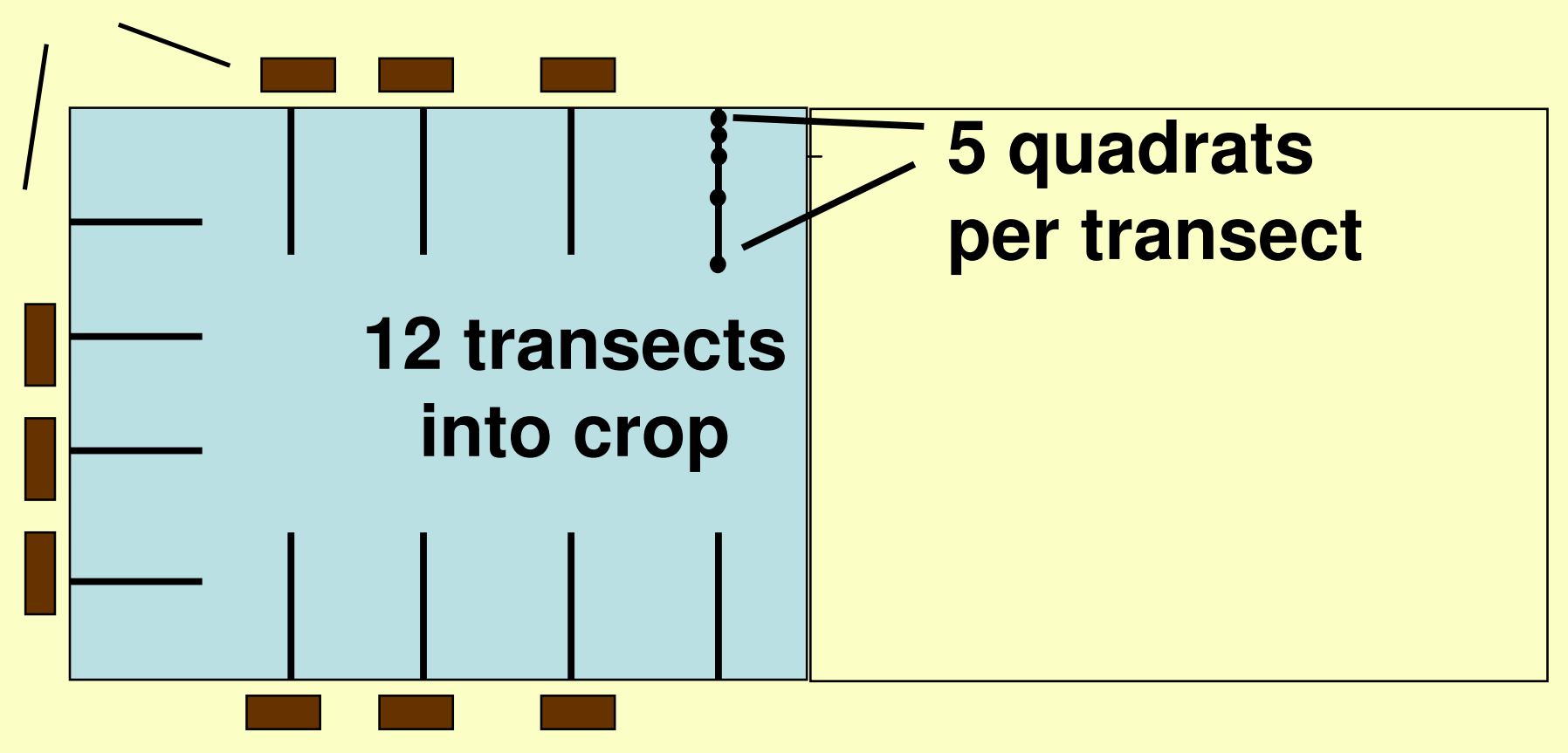




\section{Locations of trial fields in the FSE}
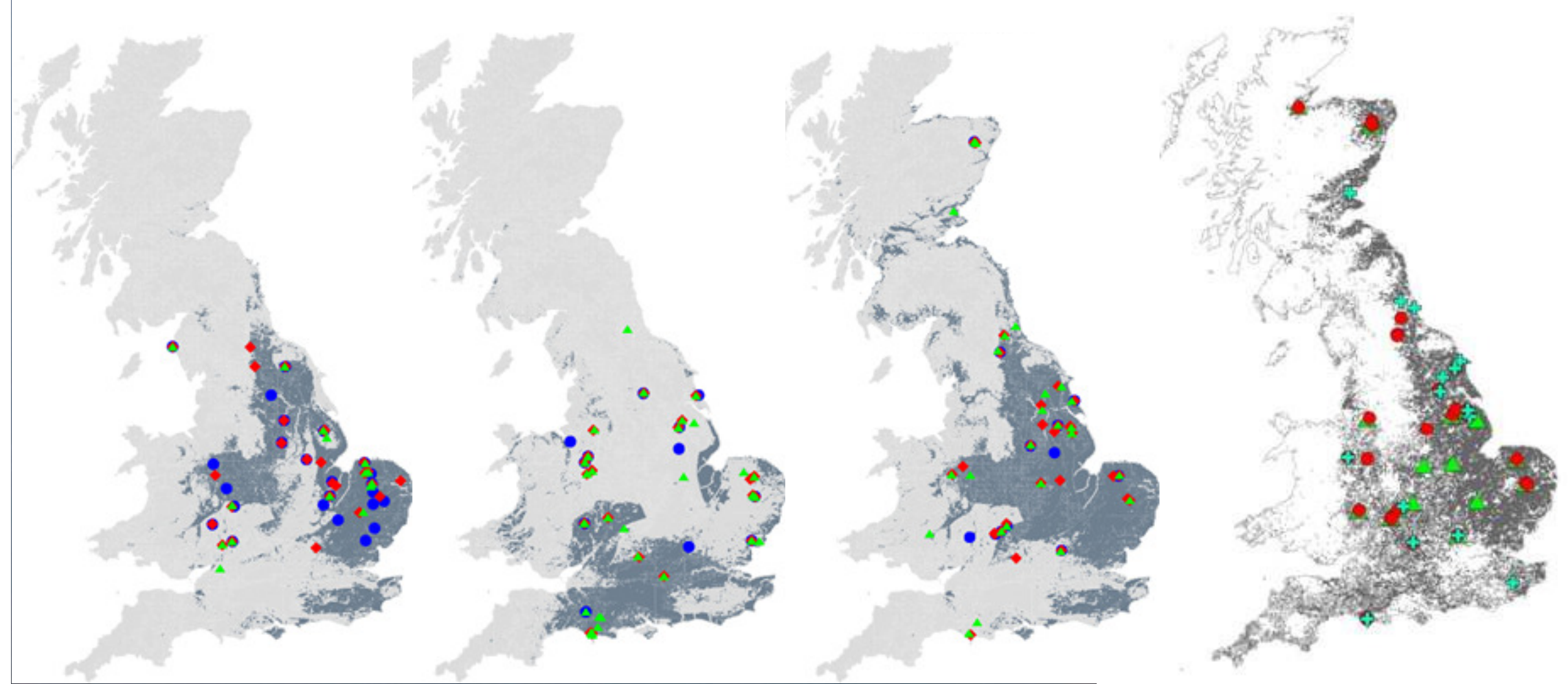

Beet (66)

Maize(68)

Spring oilseed rape (67)

Winter oilseed rape (65)

Trials were done over 3 years

Numbers in brackets were the number of fields tested Shaded areas are where the commercial crops are grown 


\section{What we did}

-In total we carried out 14 protocols

-We counted: 700,000 plants

$$
\begin{aligned}
& 17,000 \text { bees } \\
& 13,000 \text { butterflies }
\end{aligned}
$$

-We trapped: 500,000 seeds

1.5 million invertebrates

-We made $\quad>4000$ visits to fields analysed $>7000$ datasets.

Be impressed, be very impressed- Joe Perry 


\section{What it cost}

$=€ 9 \mathrm{~m}$

So be warned! 


\section{FSE Key Results}




\section{Herbicide sprays}

\begin{tabular}{|l|l|c|c|c|}
\hline Crop & \multicolumn{1}{|c|}{ Treatment } & $\begin{array}{c}\text { No of } \\
\text { sprays }\end{array}$ & $\begin{array}{c}\text { Number of } \\
\text { Al's* }\end{array}$ & $\begin{array}{c}\text { Quantity of } \\
\text { Al g/ha }\end{array}$ \\
\hline \multirow{2}{*}{ Sugar beet } & & & & \\
\cline { 2 - 5 } & GM & 1.7 & 2.0 & 1637 \\
\hline \multirow{2}{*}{ Fodder beet } & & & & \\
\cline { 2 - 5 } & GM & 1.5 & 1.8 & 1484 \\
\hline \multirow{2}{*}{ Maize } & Gonventional & 1.3 & 2.2 & 1684 \\
\cline { 2 - 5 } & GM & 1.2 & 1.3 & 965 \\
\hline $\begin{array}{l}\text { Spring } \\
\text { oilseed rape }\end{array}$ & GM & 1.7 & 1.7 & 1376 \\
\hline \multirow{2}{*}{$\begin{array}{l}\text { Winter } \\
\text { oilseed rape }\end{array}$} & GM & 1.9 & 1.9 & 1334 \\
\cline { 2 - 5 } & & & & 1690 \\
\hline
\end{tabular}




\section{Active ingredients applied to sugar beet}

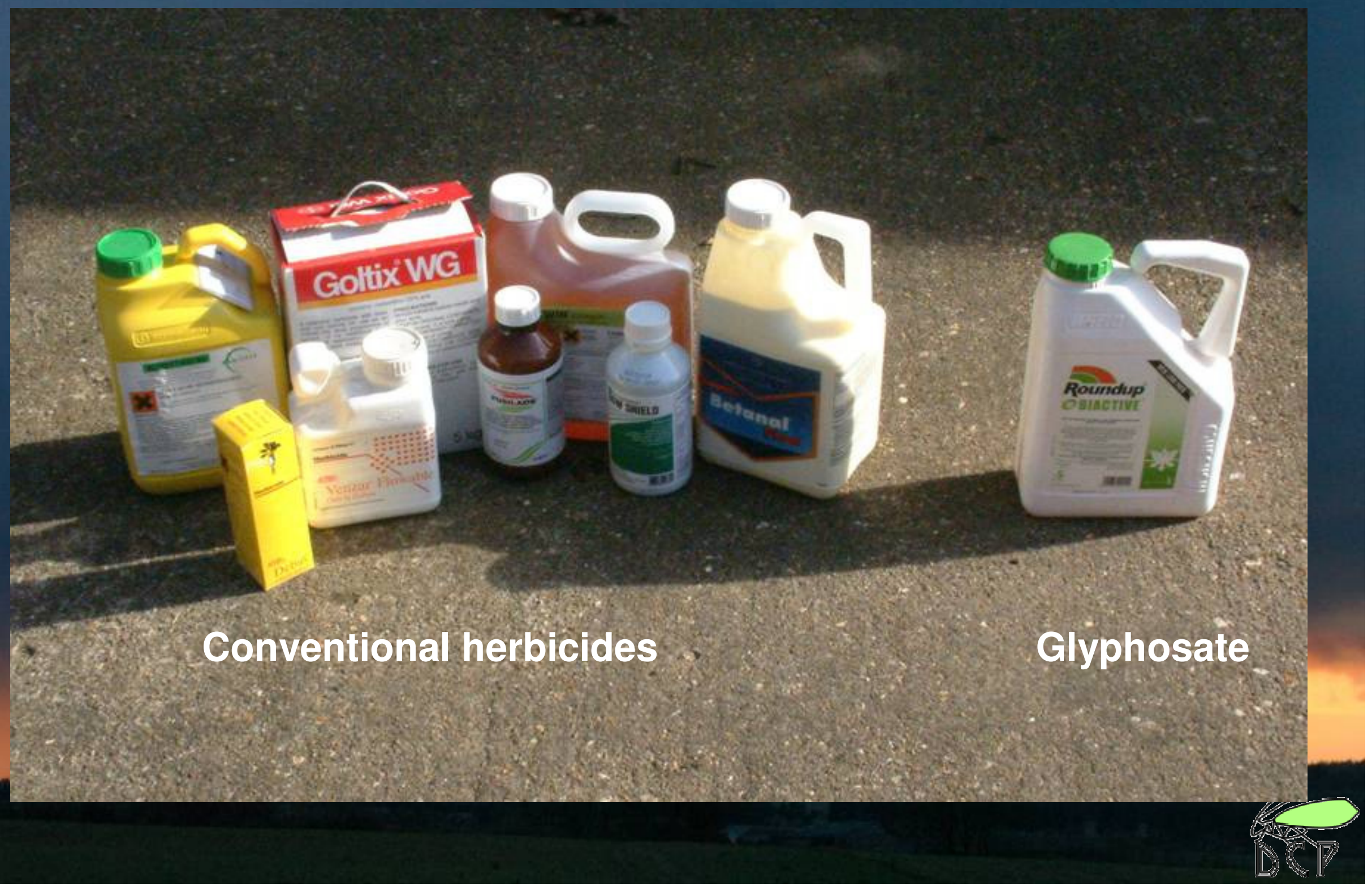




\section{Density of broad-leaved weeds: Beet}

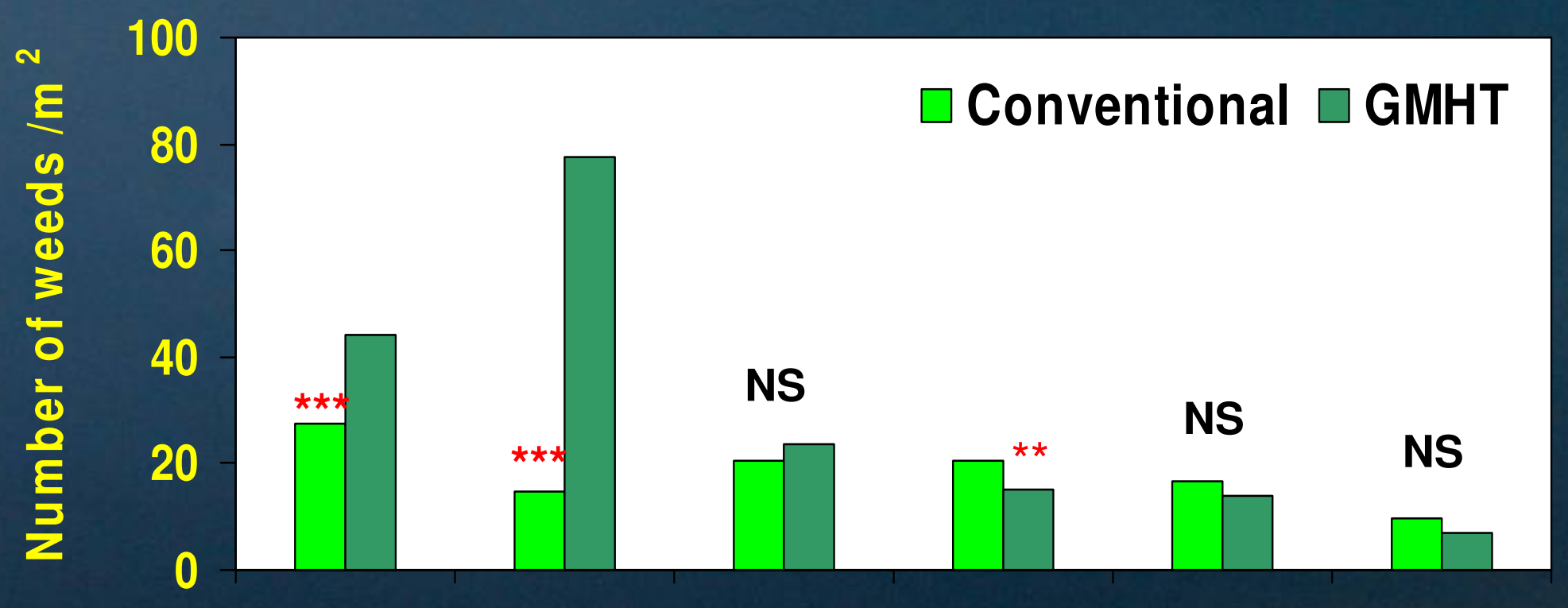

No. of sites
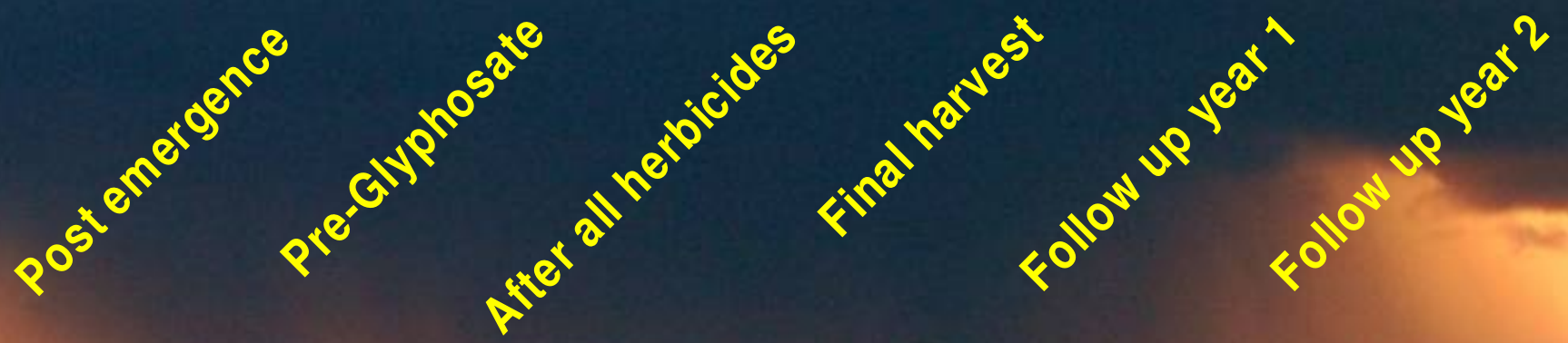

(54)

(62)

(63)

(48)

(22) 


\section{Density of broad-leaved weeds: Maize}

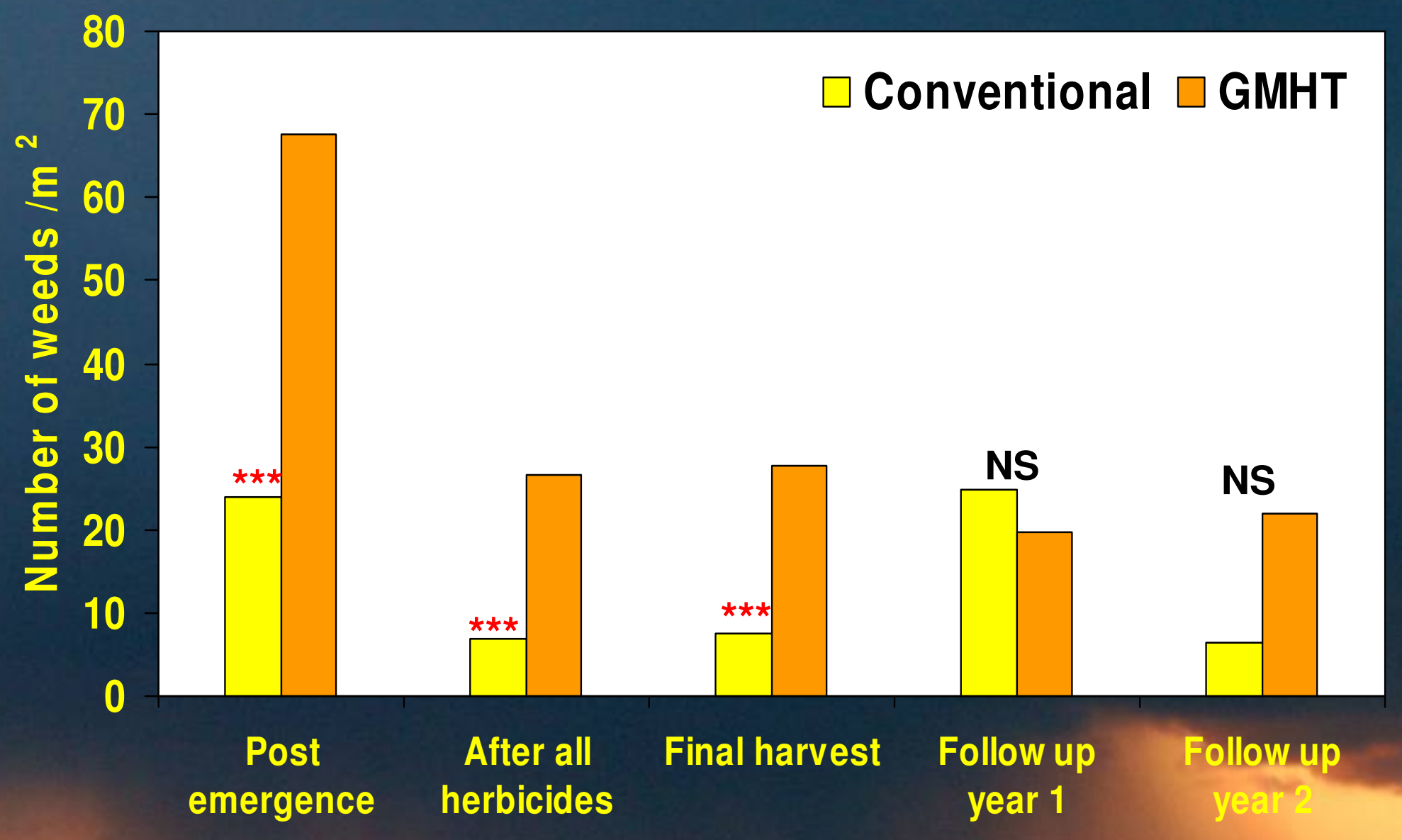

No. of sites

(58)

(52)

(45)

(15)

(6) 
Density of broad-leaved weeds:

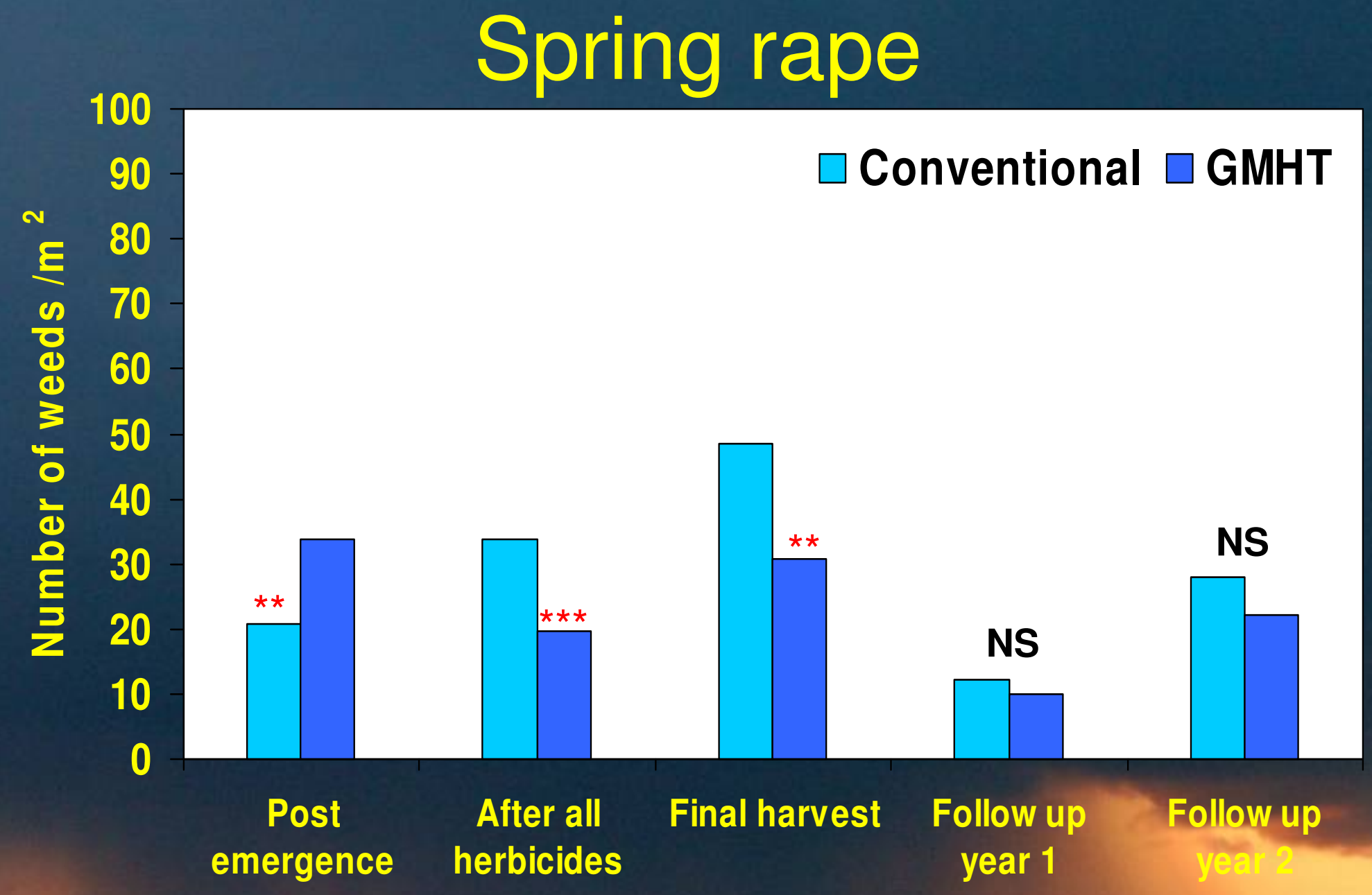

No. of sites

(65)

(62)

(63)

(38)

(9) 


\section{Density of all weeds: winter oilseed rape}

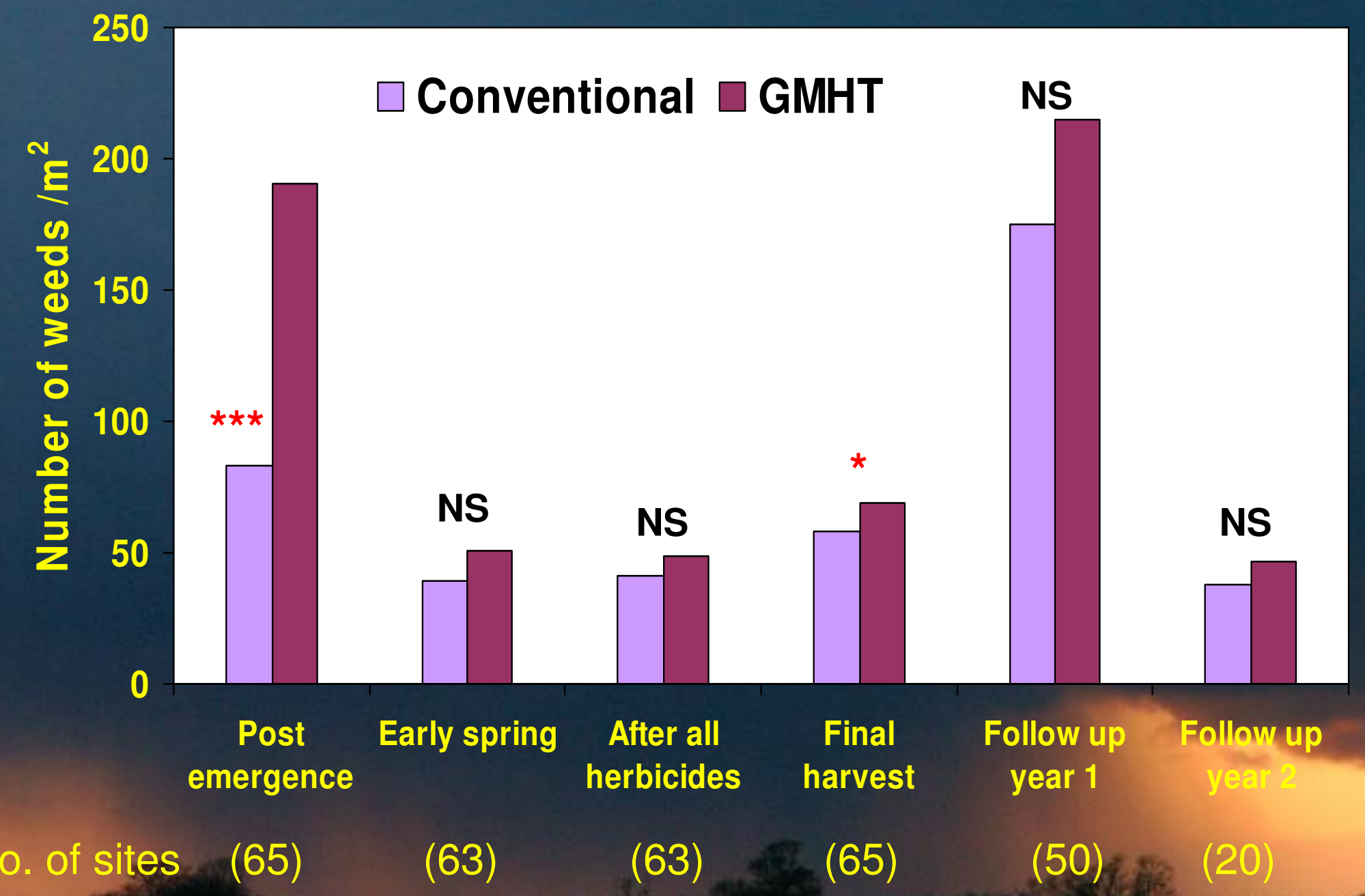




\section{Density of weeds: winter oilseed rape dicots and monocots}

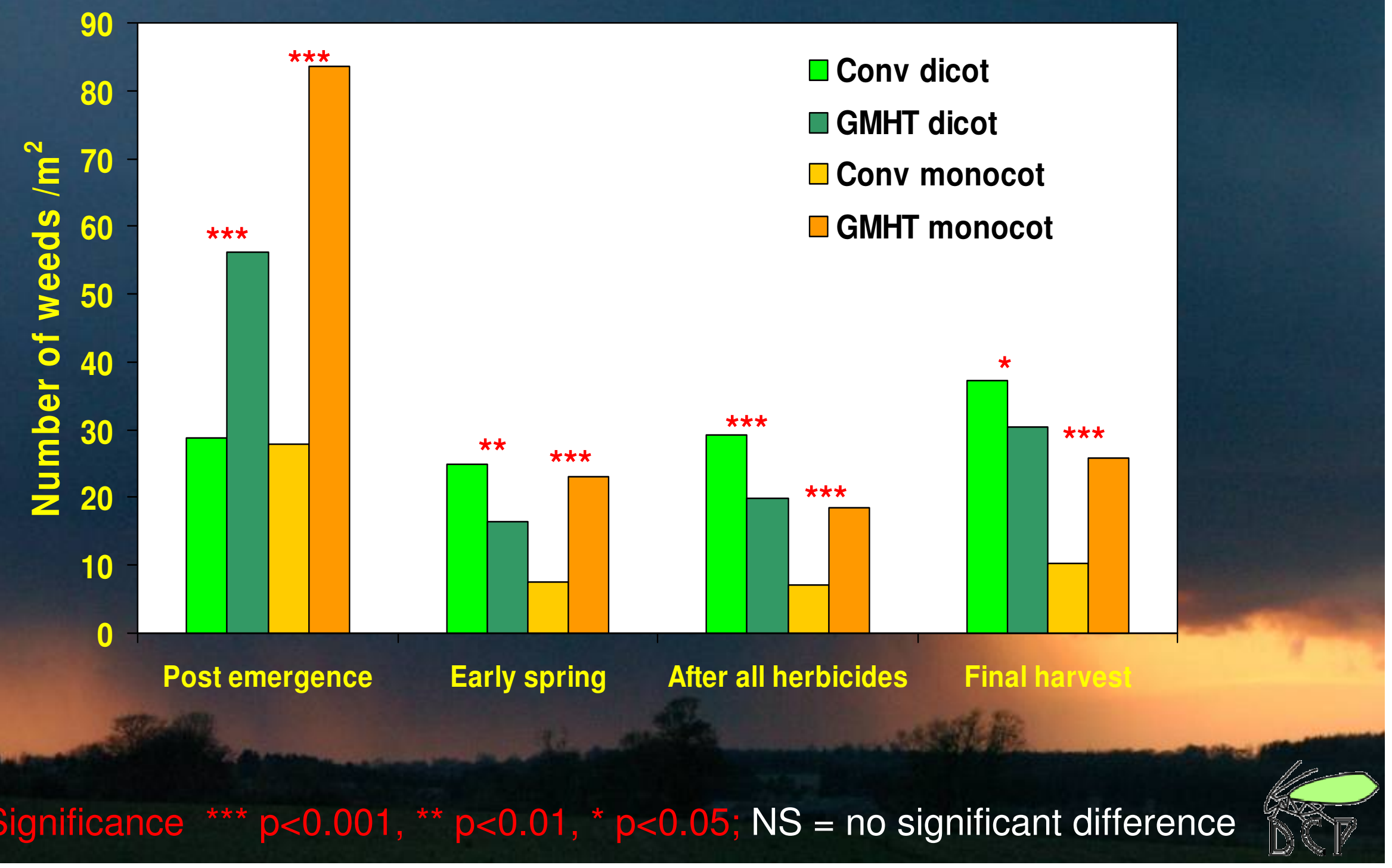




\section{Biomass of weeds at harvest}

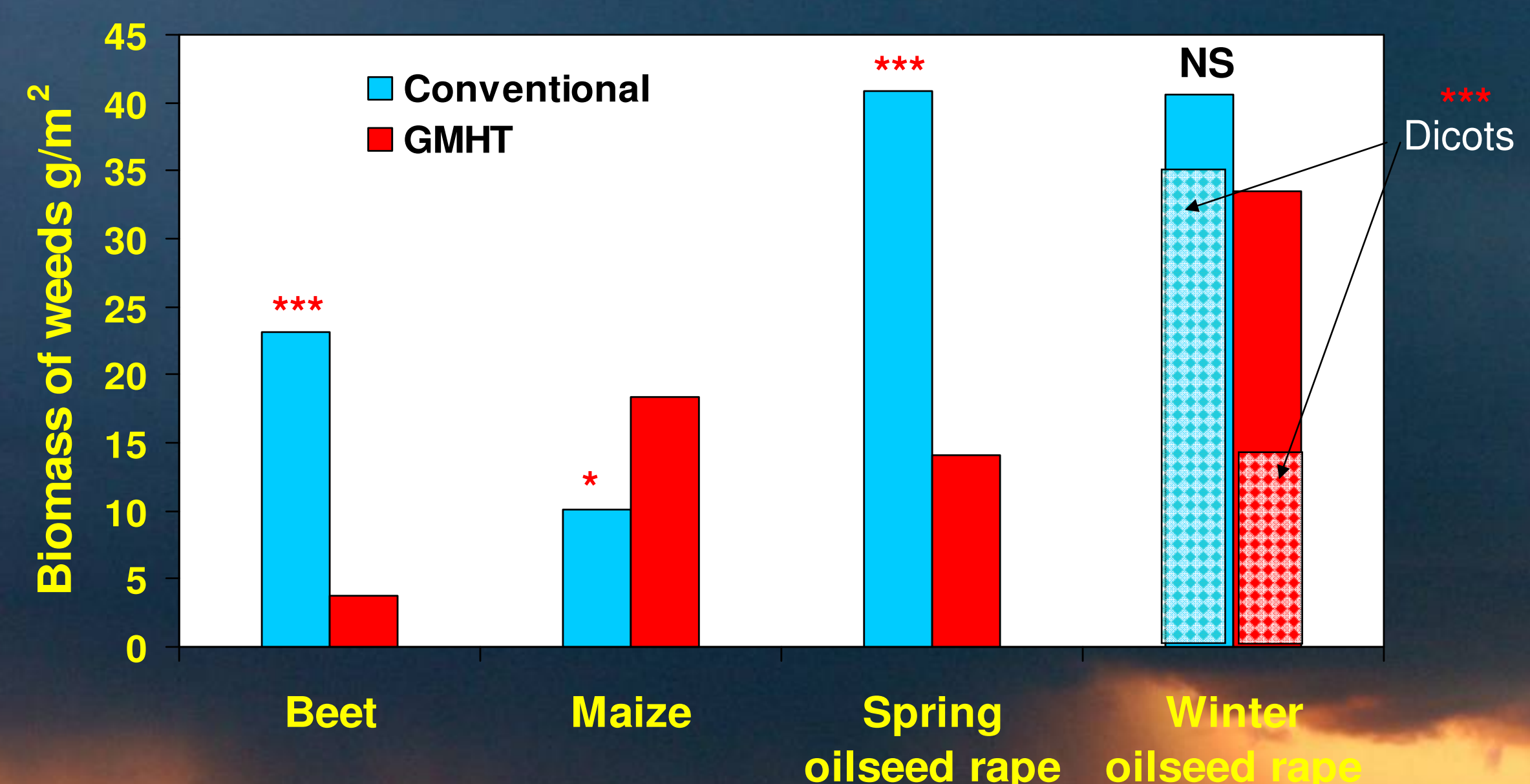

Significantly greater: ${ }^{* * *} p<0.001,{ }^{*} p<0.05 ; N S=$ no significant difference 


\section{Weed seed production: measuring seed rain}

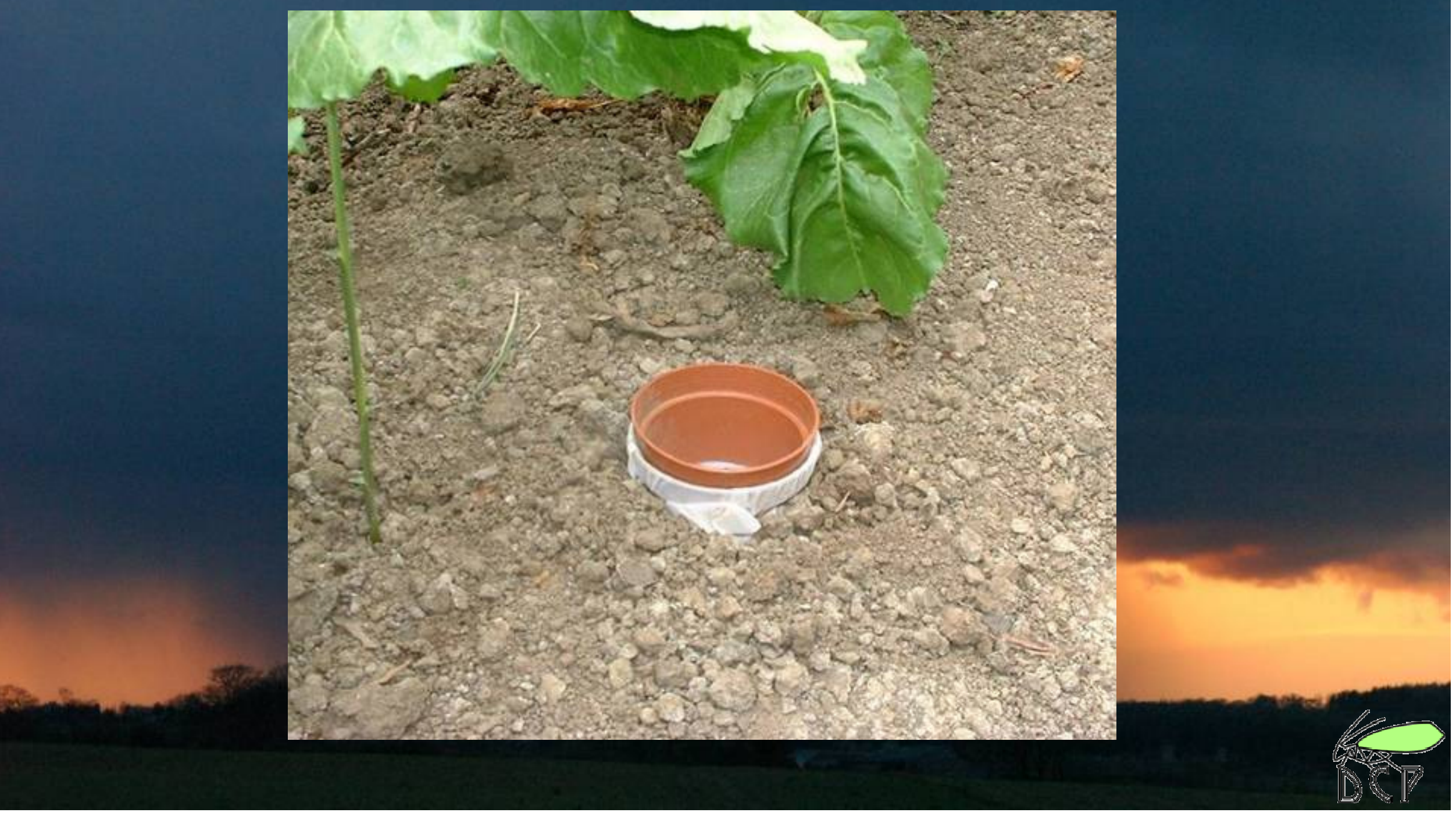




\section{Weed seed production}

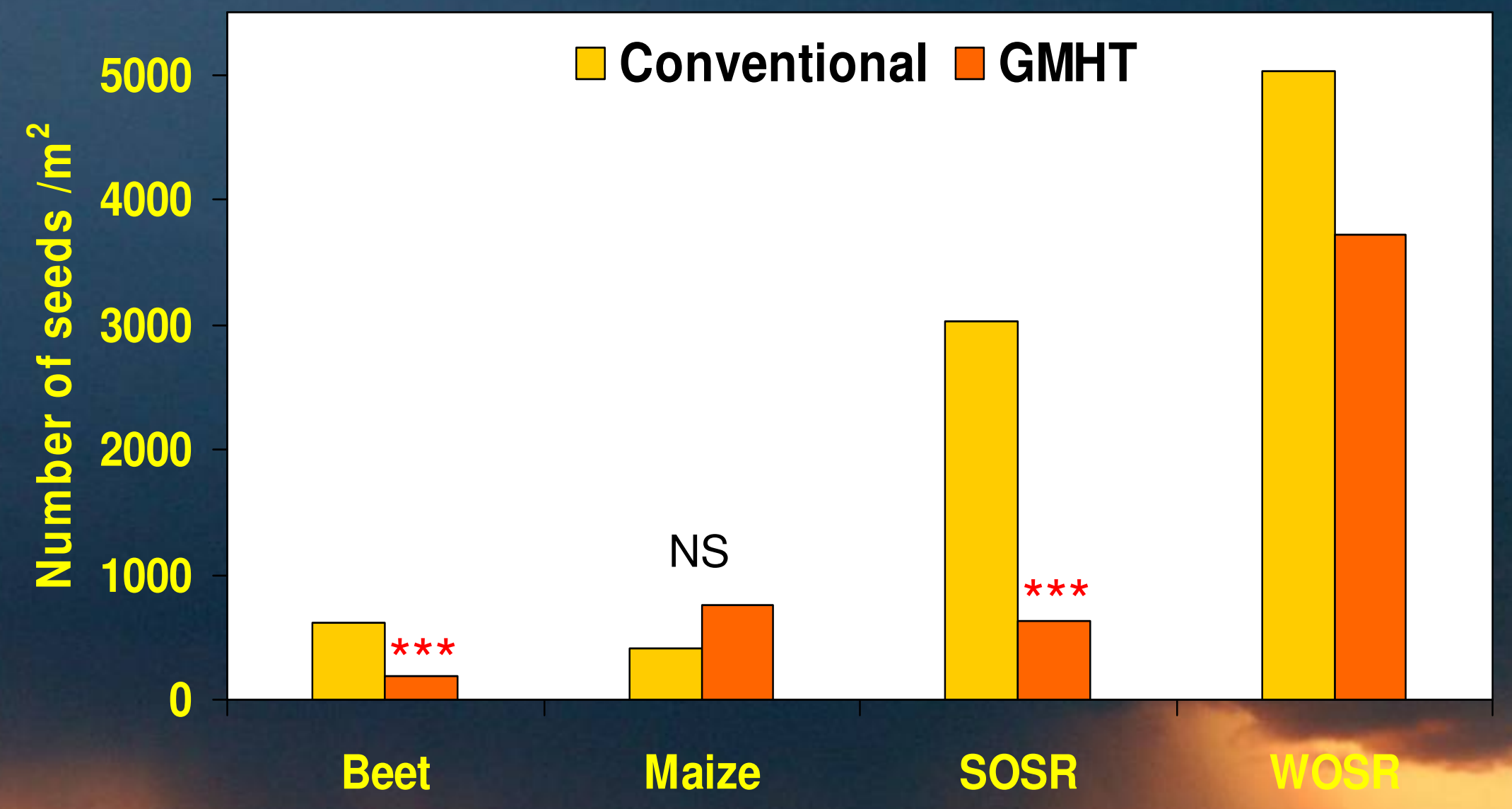

Significance $^{* * *} p<0.001 ;$ NS $=$ no significant difference 


\section{Invertebrate survey methods}
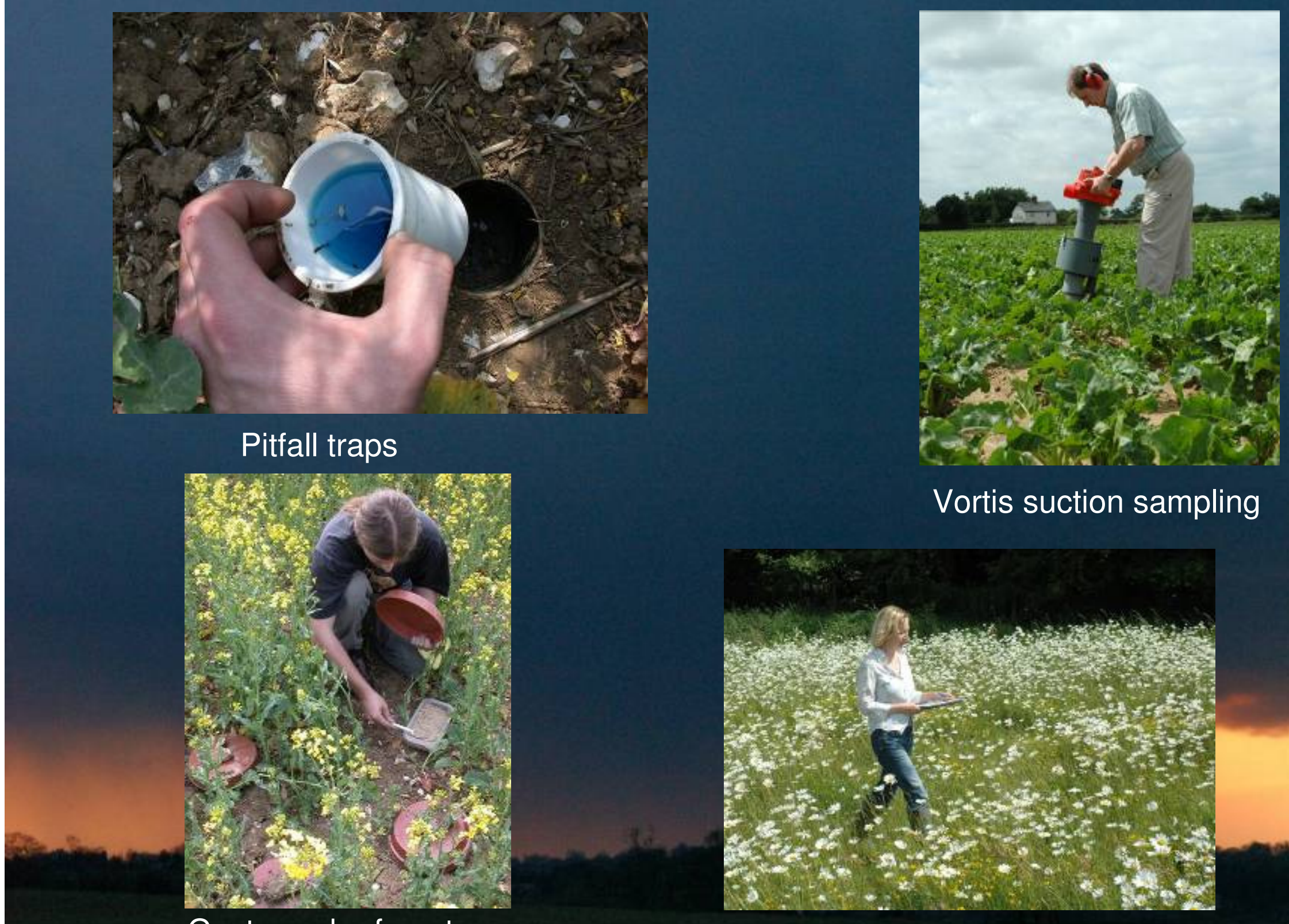

Vortis suction sampling

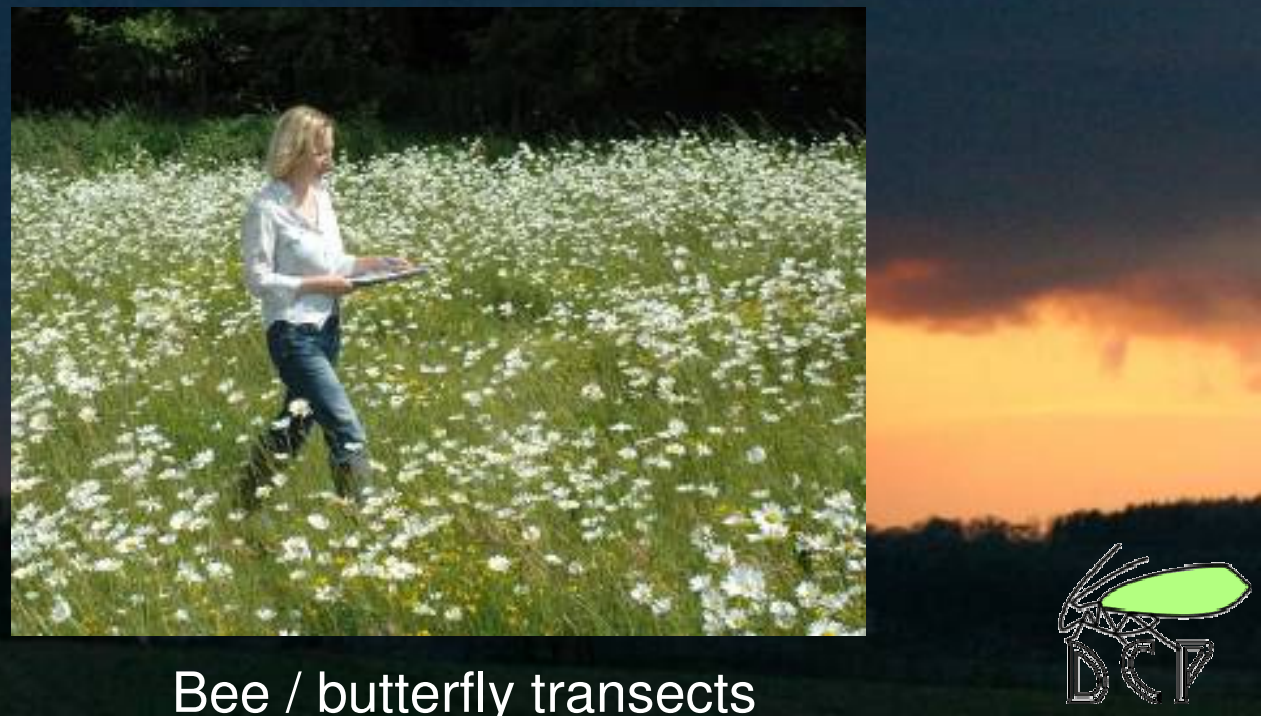




\section{Groups studied}
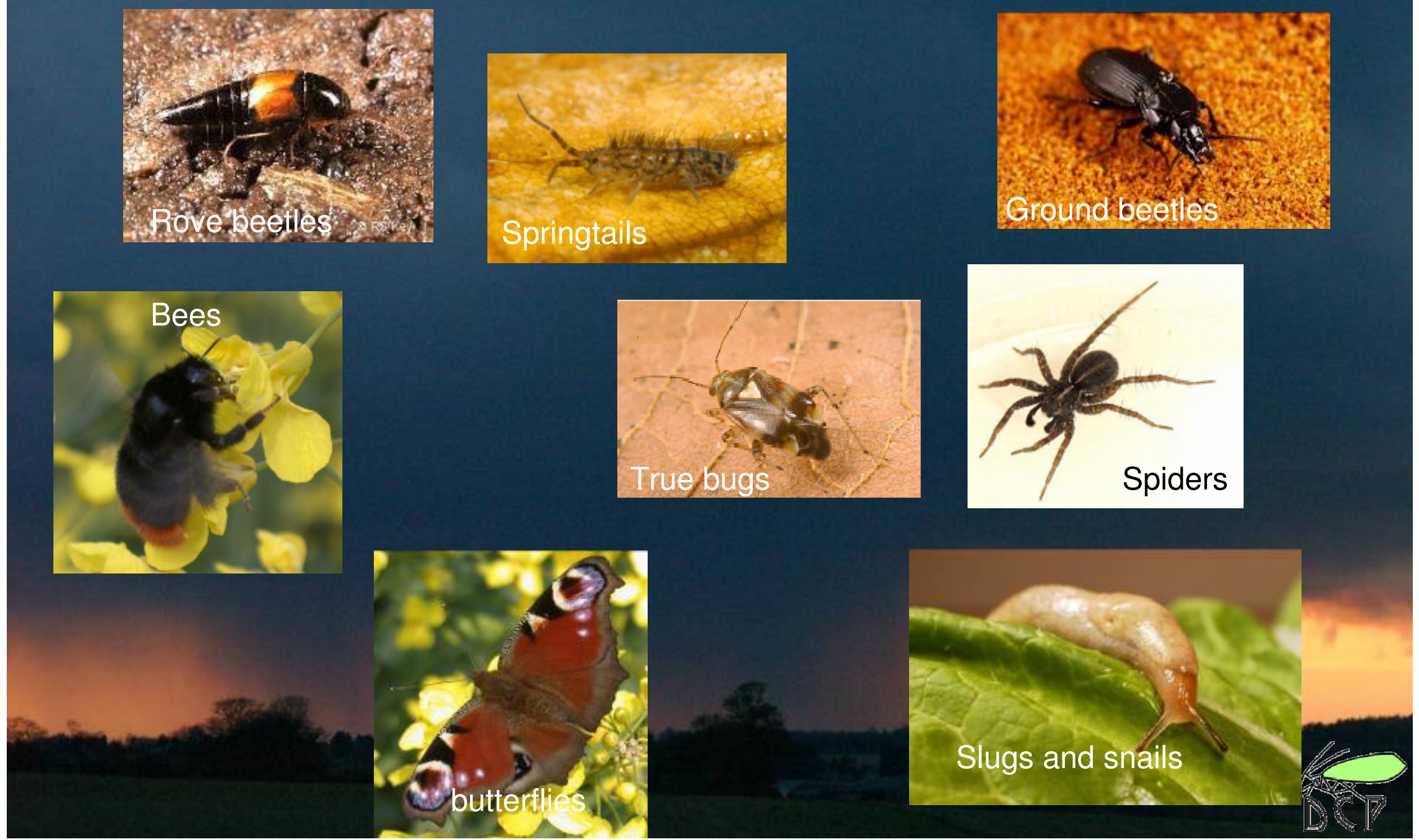


\section{Invertebrates on soil surface (pitfall traps): over whole season}

\begin{tabular}{|l|c|c|c|c|}
\hline $\begin{array}{l}\text { Invertebrate } \\
\text { group }\end{array}$ & Beet & Maize & $\begin{array}{c}\text { Spring } \\
\text { rape }\end{array}$ & $\begin{array}{c}\text { Winter } \\
\text { rape }\end{array}$ \\
\hline Carabids & No effect* & No effect & No effect & No effect \\
\hline Staphylinids & No effect & No effect & No effect & No effect \\
\hline Spiders & No effect* & No effect* & No effect* & No effect* \\
\hline Springtails & No effect* & No effect* & No effect* & More in \\
\hline Slugs & No effect & No effect & No effect* & No effect \\
\hline
\end{tabular}

* Some significant effects on some occasions with some species or families (A) 


\section{Pests and natural enemies on crop plants over whole season}

\begin{tabular}{|l|c|c|c|}
\hline Pest & Beet & Maize & Spring rape \\
\hline Aphids & No effect & No effect & No effect \\
\hline Thrips & - & No effect & - \\
\hline $\begin{array}{l}\text { Pollen } \\
\text { beetles }\end{array}$ & - & - & No effect \\
\hline Predators & No effect & No effect* & No effect \\
\hline Parasitoids & No effect* & No effect & No effect \\
\hline
\end{tabular}




\section{Invertebrates in Vortis samples over whole season}

\begin{tabular}{|l|c|c|c|c|}
\hline Group & Beet & Maize & $\begin{array}{c}\text { Spring } \\
\text { rape }\end{array}$ & $\begin{array}{c}\text { Winter } \\
\text { rape }\end{array}$ \\
\hline Spiders & No effect & No effect & No effect & No effect \\
\hline Springtails & No effect & $\begin{array}{c}\text { More in } \\
\text { GMHT }\end{array}$ & No effect & No effect \\
\hline $\begin{array}{l}\text { Ground } \\
\text { beetles }\end{array}$ & No effect & No effect & No effect & No effect \\
\hline True bugs & $\begin{array}{c}\text { More in } \\
\text { conv }\end{array}$ & No effect & No effect & No effect \\
\hline
\end{tabular}




\section{Bees in crops}

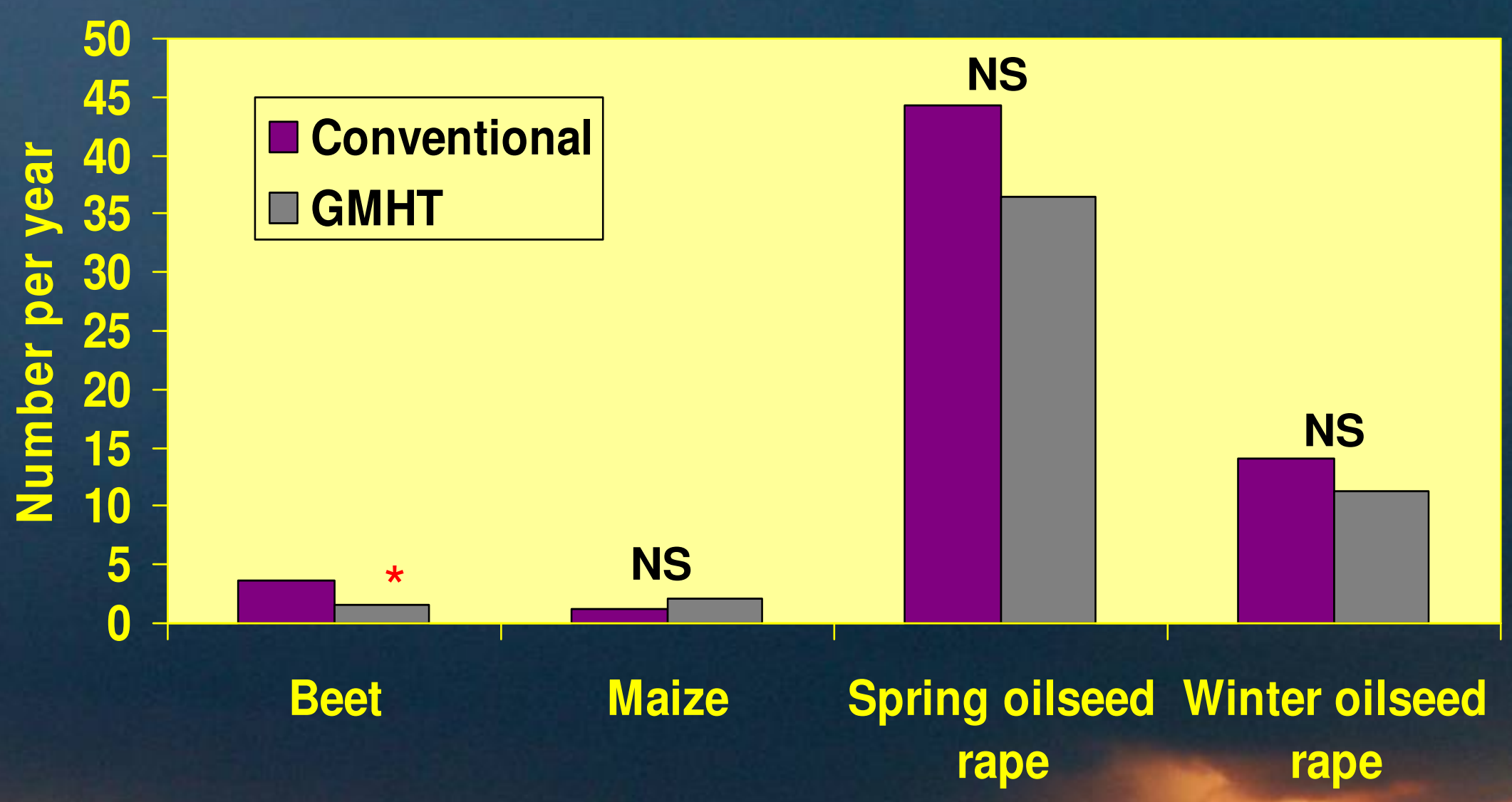

Crop 


\section{Significant effects in beet caused by presence of thistles}
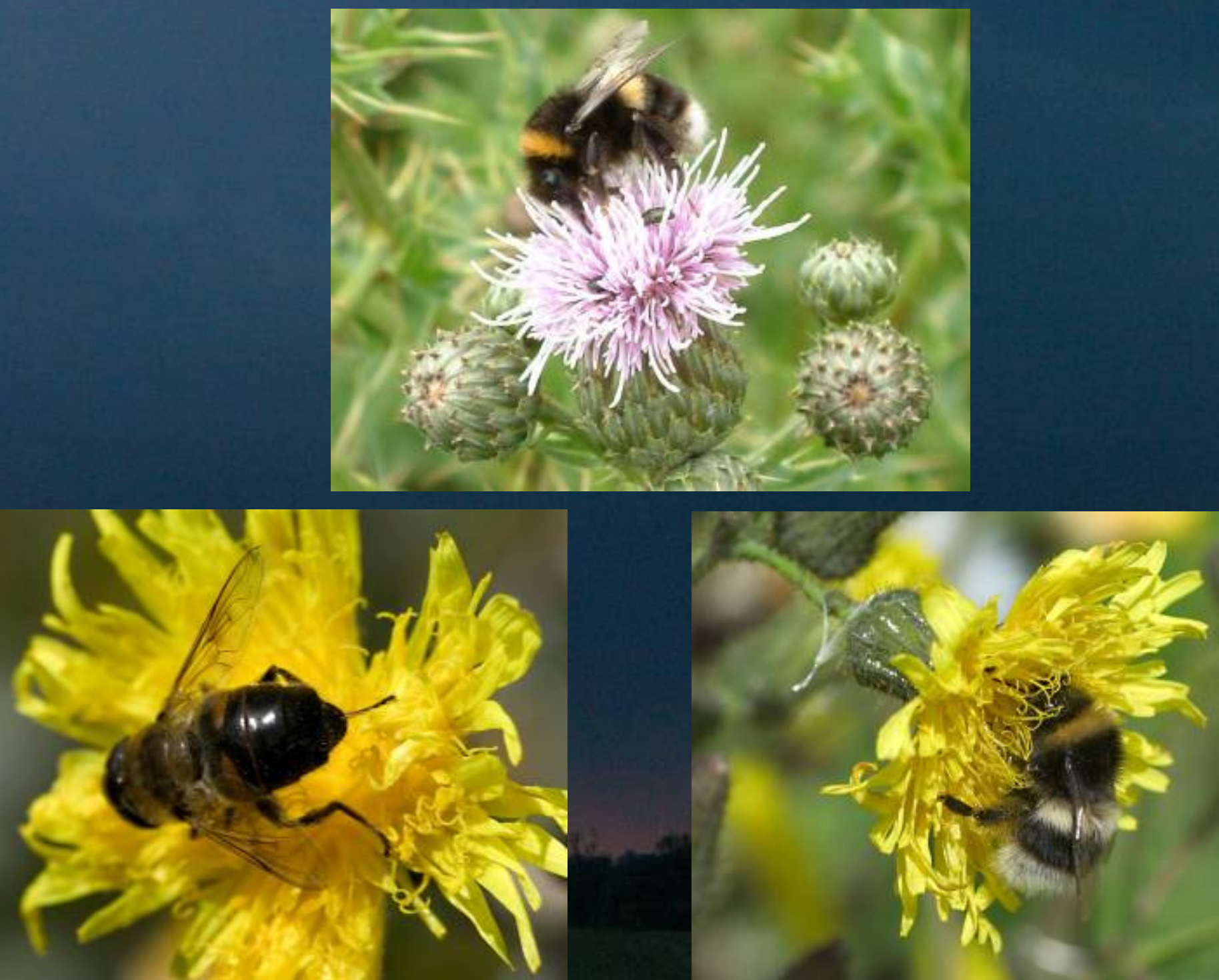


\section{Butterflies in crops}

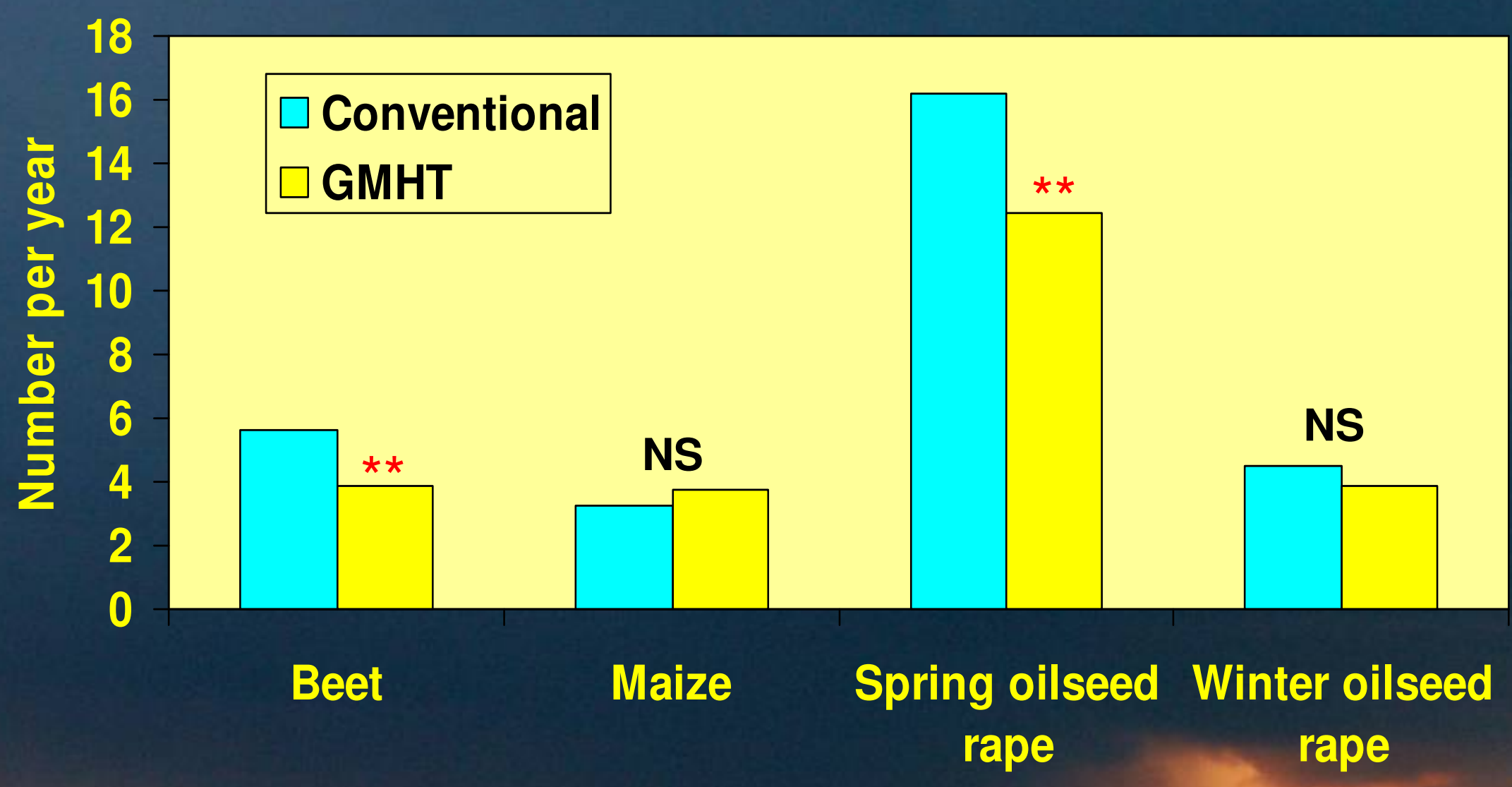

Crop 


\section{Comparison of crops: Density of weeds just pre-harvest}

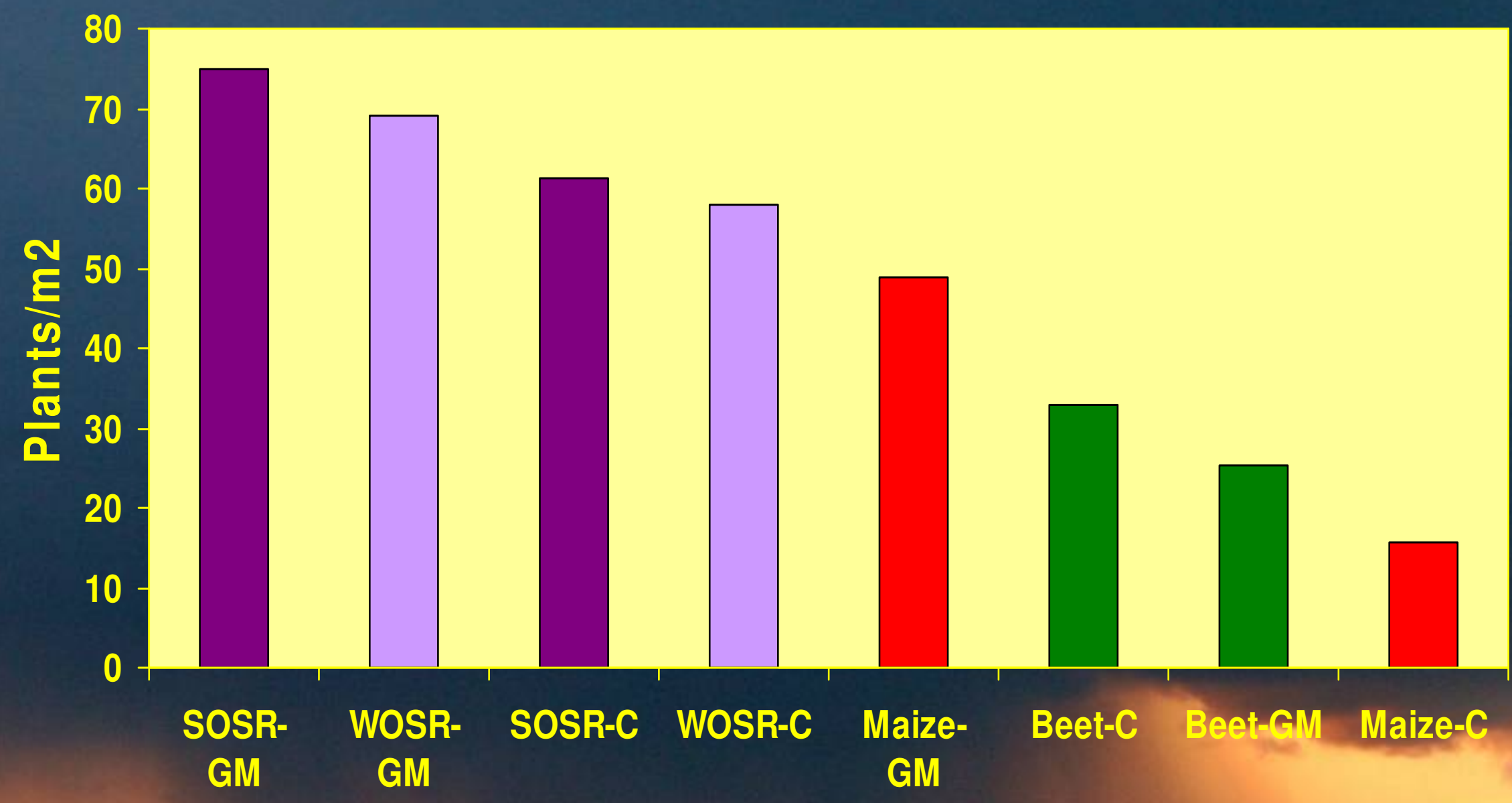

Crop

Heard et al, 2003: Phil. Trans. R. Soc. Lond. B: 358, 1819-1832

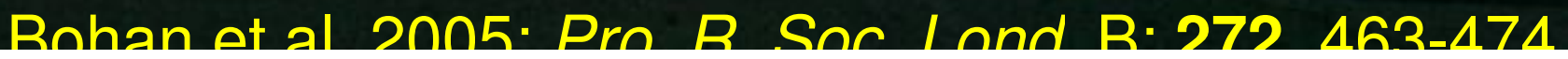




\section{Comparison of crops: Total seed rain - whole season}

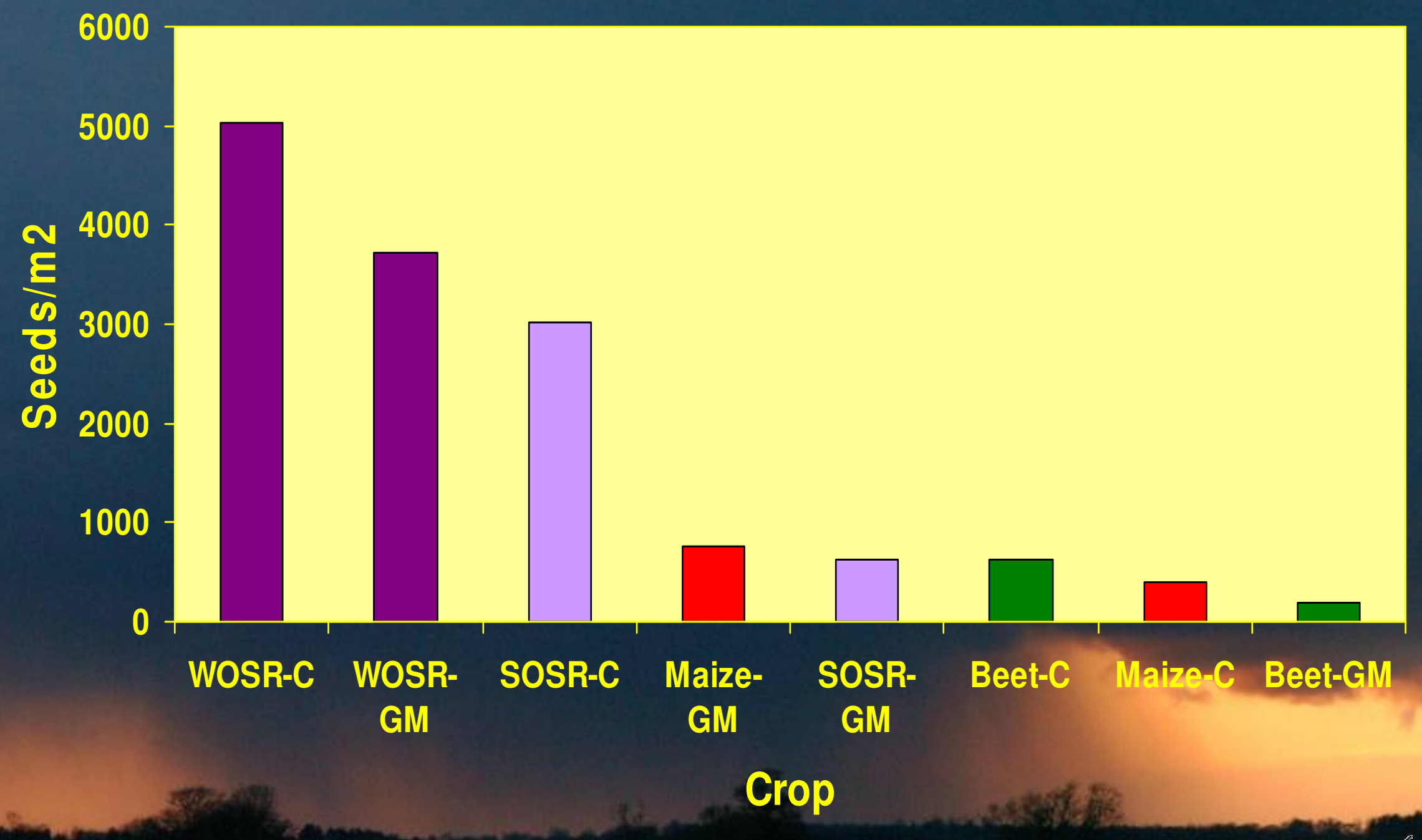

Heard et al, 2003: Phil. Trans. R. Soc. Lond. B: 358, 1819-1832 Rohan atal 2005. Drn $R$ Sos L and B. 272 162-4.74 


\section{Comparison of crops: Invertebrates in pitfall traps- whole season}

$\square$ Carabids $\square$ Staphylinids $\square$ Spiders $\square$ Collembola

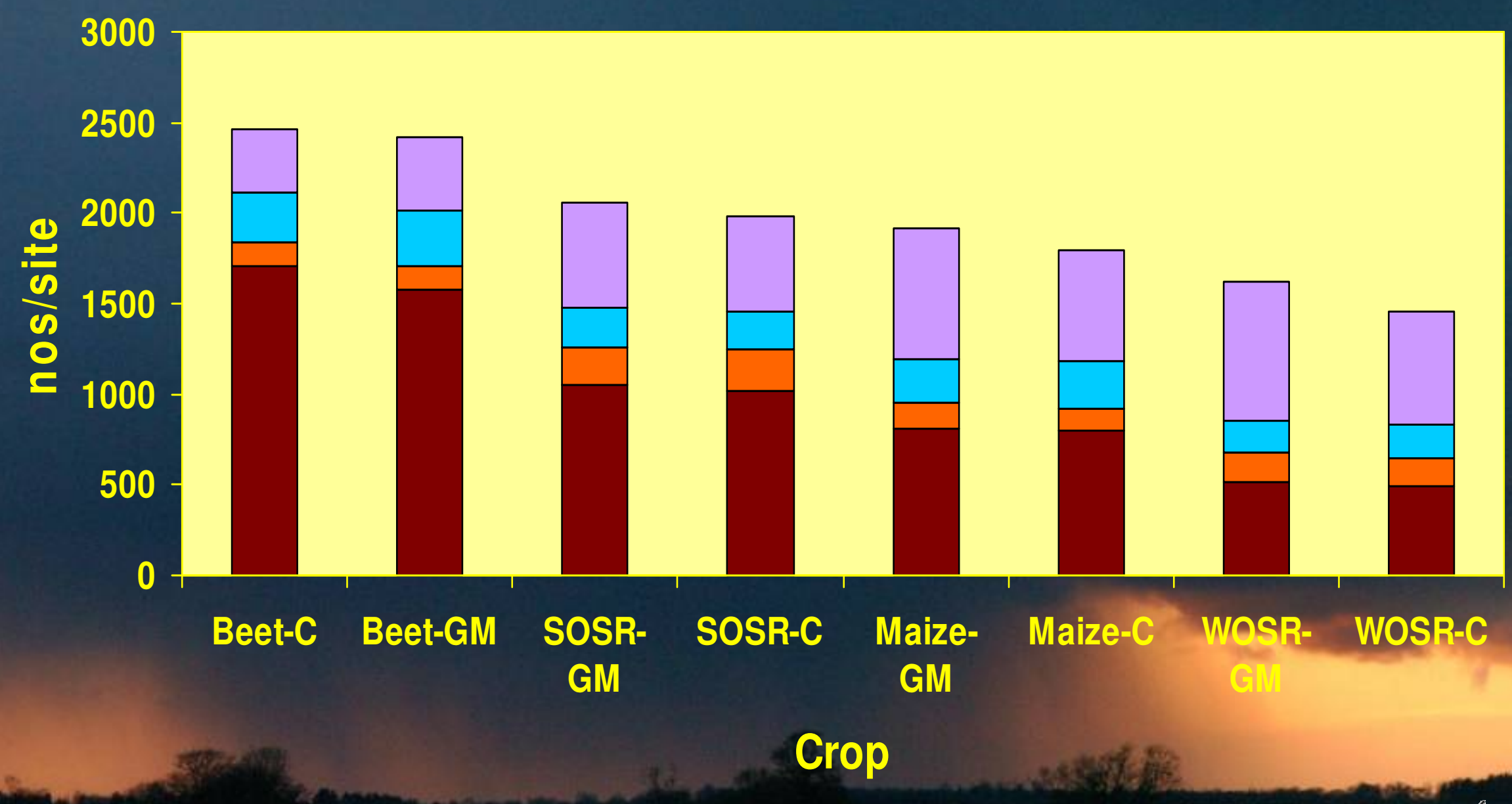

Brooks et al, 2003: Phil. Trans. R. Soc. Lond. B: 358, 1847-1862 Rohan et_al 2005. Dro $R$ Sos Land R. 272 162-474. 


\section{Comparison of crops: \\ Invertebrates in Vortis samples - whole season}

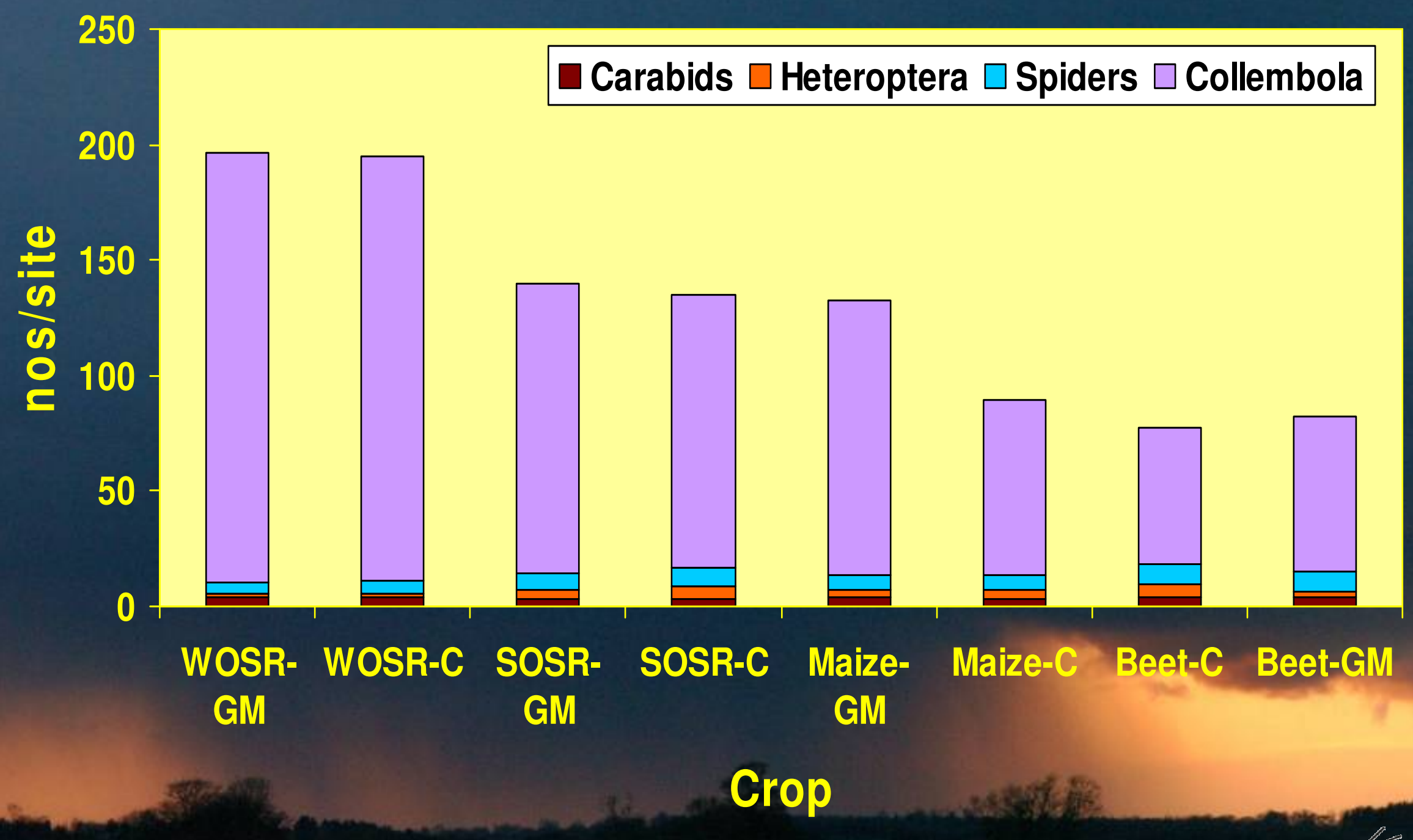

Haughton et al, 2003: Phil. Trans. R. Soc. Lond. B: 358, 1863-1877 Bohan stal 2005. Pro $R$ Son Lnod R. 272 162-474. 


\section{Conclusions}

- Fewer herbicides were used in the GMHT halves of three of the four crops

- Herbicide treatments produced fewer weeds, weed biomass and seeds in GMHT beet and spring and winter rape, but more in maize

- These differences were due to the efficiency of control of the various herbicide regimes, NOT GMHT PER SE 


\section{Conclusions: consequences}

- No overall effects on ground beetles, rove beetles, spiders, springtails, slugs, pests, but some effects on individual species on some occasions consistent with diet

- Fewer butterflies in GMHT beet and rape, but differences larger between crops

- Fewer bees in GMHT beet 


\section{Key References}

- For beet, maize and spring rape, Special issue of :

- Philosophical Transactions of the Royal Society Volume 358; No.1439, 1773 - 1913.

- Bohan et al 2005: (winter oilseed rape only)

- Proceedings of the Royal Society B, 272, 463474.

- Dewar et al, 2005 (for summary)

- Outlooks on Pest Management, 16(4),164-173 


\section{Outcome}

- The UK government banned the growing of GMHT oilseed rape and beet, but approved the growing of GMHT maize so long as it was grown like those in the FSE

- Bayer (formerly Aventis) withdrew the variety of GMHT maize that was used in the FSE, so no GMHT crops have since been grown in the UK 


\section{Cost of protocols in the FSE*}

\begin{tabular}{|l|c|l|c|}
\hline Protocol & Cost/site & Protocol & Cost/site \\
\hline Field layout & $£ 357$ & Seed rain & $£ 2552$ \\
\hline Seedbank & $£ 2297$ & Bees \& butterflies & $£ 418$ \\
\hline Follow-up seedbank & $£ 4548$ & Insects on crops & $£ 344$ \\
\hline Crop assessment & $£ 782$ & Vortis & $£ 1208$ \\
\hline Weeds in fields & $£ 2066$ & Pitfall traps & $£ 3000$ \\
\hline Weeds in margins & $£ 566$ & Gastropods $(\mathfrak{f}+\mathrm{m})$ & $£ 713$ \\
\hline Follow-up weeds & $£ 601$ & TOTAL & $£ 19453$ \\
\hline
\end{tabular}

*At 2002 prices; subsample of 113 /266 sites

-From Qi et al (2008) Annals of Applied Biology 152, 93-101 


\section{Effects of GMHT crops on birds 1}

- In beet and spring oilseed rape, rain of weed seeds important in the diets of 16 bird species was significantly reduced in GMHT compared to conventional halves; for no species did it increase.

- In winter oilseed rape, rain of weed seeds important in the diets of 10 species was significantly reduced in GMHT halves; for only one species did it increase significantly.

- By contrast, in maize, rain of weed seeds important in the diets of seven species was significantly greater in GMHT halves; for no species was it reduced.

Gibbons et al 2006, Proc. R. Soc. B 2006 273, 1921-1928 


\section{Predicted effects of GMHT crops on Farmland Bird Index (FBI)*}

\begin{tabular}{|l|c|c|c|}
\hline $\begin{array}{l}\text { FBI in } \\
2001\end{array}$ & \multicolumn{3}{|c|}{ Predicted FBI in 2020 } \\
\hline & $\begin{array}{c}\text { Current land } \\
\text { management } \\
\text { continued }\end{array}$ & $\begin{array}{c}\text { GMHT crops } \\
\text { introduced in } \\
2005\end{array}$ & $\begin{array}{c}\text { ELS } \\
\text { introduced in } \\
2005\end{array}$ \\
\hline 0.54 & 0.42 & 0.40 & 0.47 \\
\hline
\end{tabular}

ELS = Entry Level Stewardship agri-environment scheme * Includes 39 species of farmland birds 


\section{Predicted effects of GMHT crops on Farmland Bird Index (FBI)}

“...GMHT crops would only have a limited effect on FBI” ...

However, despite employment of agri-environment schemes

"...the FBI will continue to decline driven by detrimental conditions persisting in the cropped area"

Butler et al (2007). Science 315, 381-384 


\section{Gene flow to non GM crops}

- Survey conducted by Central Science Laboratory (CSL, now FERA)

- Only oilseed rape and maize crops sampled.

- In maize, gene flow was detected up to $200 \mathrm{~m}$ from GM source

- Recommended separation distance $=3 \mathrm{~m}$ to comply with $<0.9 \%$ 'cross pollination' threshold

- Weekes et al (2007) Transgenic research 16(2), 203-211

- In OSR, a model predicted cross pollination of $0.04 \%$ in WOSR, $0.02 \%$ in SOSR at $50 \mathrm{~m}$ from the source

- Weekes et al (2005) Transgenic Research 14(5), 749-759 


\section{Development of herbicide-resistant weeds}

- There are 18 species now recorded as being resistant to glyphosate (http://www. weedscience.org//n.asp )

- Many are associated with glyphosate usage in GMHT crops

- The solution is to adopt crop rotations and cultivation systems in which weed control is not dependent on only one herbicide 


\section{Mitigation measures}

- Set-aside headland

- Better margin management

- In crop weed-refugia

- Less intense weed management

- Band-spraying

- Reduced tillage

- Overwintered stubbles 


\section{A win:win vision for agriculture \& environment}

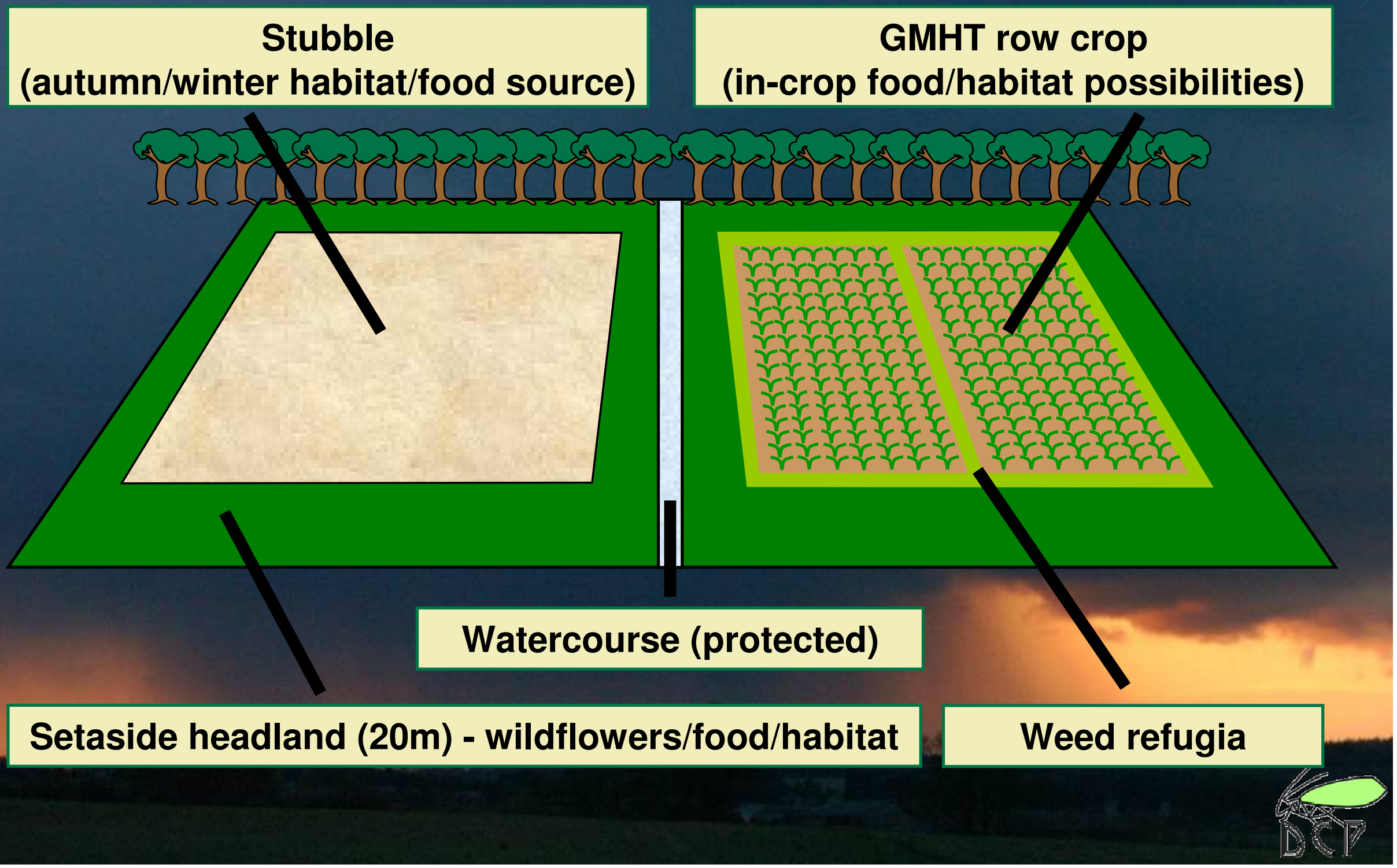




\section{The End}

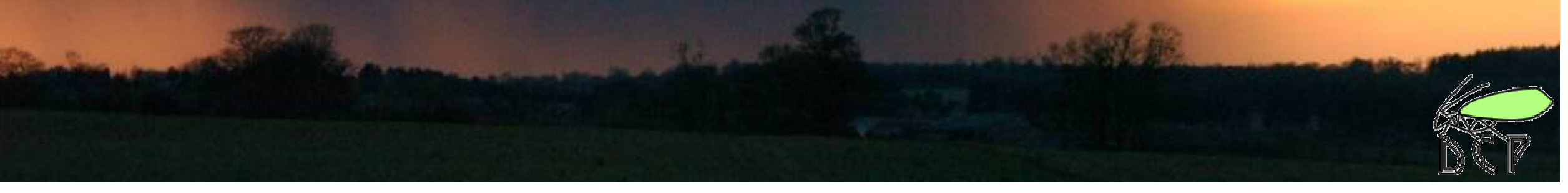

